\title{
Cytotoxicity and Proapoptotic Effects of Allium atroviolaceum Flower Extract by Modulating Cell Cycle Arrest and Caspase-Dependent and p53-Independent Pathway in Breast Cancer Cell Lines
}

\author{
Somayeh Khazaei, ${ }^{1}$ Roslida Abdul Hamid, ${ }^{1}$ \\ Vasudevan Ramachandran, ${ }^{2}$ Norhaizan Mohd Esa, ${ }^{3}$ Ashok Kumar Pandurangan, ${ }^{4}$ \\ Fatemeh Danazadeh, ${ }^{1}$ and Patimah Ismail ${ }^{1}$ \\ ${ }^{1}$ Department of Biomedical Science, Faculty of Medicine and Health Sciences, Universiti Putra Malaysia, Selangor, Malaysia \\ ${ }^{2}$ Malaysian Research Institute of Aging, Universiti Putra Malaysia, Selangor, Malaysia \\ ${ }^{3}$ Department of Nutrition and Dietetics, Faculty of Medicine and Health Sciences, Universiti Putra Malaysia, Selangor, Malaysia \\ ${ }^{4}$ School of Life Sciences, B. S. Abdur Rahman Crescent University, Vandalur, Chennai, Tamil Nadu 600048, India
}

Correspondence should be addressed to Patimah Ismail; patimahismail@gmail.com

Received 1 June 2017; Accepted 12 October 2017; Published 8 November 2017

Academic Editor: José L. Rios

Copyright (C) 2017 Somayeh Khazaei et al. This is an open access article distributed under the Creative Commons Attribution License, which permits unrestricted use, distribution, and reproduction in any medium, provided the original work is properly cited.

\begin{abstract}
Breast cancer is the second leading cause of cancer death among women and despite significant advances in therapy, it remains a critical health problem worldwide. Allium atroviolaceum is an herbaceous plant, with limited information about the therapeutic capability. We aimed to study the anticancer effect of flower extract and the mechanisms of action in MCF-7 and MDA-MB-231. The extract inhibits the proliferation of the cells in a time- and dose-dependent manner. The underlying mechanism involved the stimulation of S and G2/M phase arrest in MCF-7 and S phase arrest in MDA-MB-231 associated with decreased level of Cdk1, in a $p 53$-independent pathway. Furthermore, the extract induces apoptosis in both cell lines, as indicated by the percentage of sub-G0 population, the morphological changes observed by phase contrast and fluorescent microscopy, and increase in Annexin$\mathrm{V}$-positive cells. The apoptosis induction was related to downregulation of $\mathrm{Bcl}$-2 and also likely to be caspase-dependent. Moreover, the combination of the extract and tamoxifen exhibits synergistic effect, suggesting that it can complement current chemotherapy. LC-MS analysis displayed 17 major compounds in the extract which might be responsible for the observed effects. Overall, this study demonstrates the potential applications of Allium atroviolaceum extract as an anticancer drug for breast cancer treatment.
\end{abstract}

\section{Introduction}

After lung cancer, breast cancer is the second leading cause of cancer death among women worldwide. Among more than one million new cancer cases, breast cancer contains $18 \%$ of all female cancers globally [1]. Despite significant advances in therapy, breast cancer remains a critical health problem worldwide. Moreover, the current breast cancer treatments are expensive, not widely available, and limited by side effects and resistance to the treatment. Therefore, natural products could be the alternative and novel anticancer agents $[2,3]$. Natural crude extracts and biologically active compounds isolated from plant species used in traditional medicine can be prolific resources for new drugs [4]. Allium atroviolaceum (A. atroviolaceum), an herbaceous, perennial, bulbous plant, is a species in the genus Allium which belongs to the Alliaceae family. It is distributed in Crimea, Caucasus (Ante-Caucasus, Daghestan, and Trans-Caucasus), middle Asia (Mountainous Turkmenistan, Syr-Darya foothill areas), and Iran [5]. A. atroviolaceum is used as food (vegetable) and 
a source of vitamins, although useful properties of this species have not been studied adequately [6]. Gas chromatographymass spectrophotometry study on A. atroviolaceum revealed the presence of various bioactive components in the plant extracts which might be the reason of antioxidant and antibacterial potency and perhaps other biological activities [7]. Notably, Allium vegetables are rich in flavonols and organosulfur compounds, which have exhibited tumor inhibitory properties in laboratory studies. Some components of Allium vegetables are reported to block several stages of carcinogenesis, although the underlying mechanisms of action are generally unclear [8]. The previous studies on $A$. atroviolaceum bulb extract against breast, cervical, and liver cancers [9] and flower extracts against HepG2 [10] and Hela [11] cells demonstrated potential anticancer activity.

In current study methanol extract from flower of $A$. atroviolaceum (FAA) has been used in scientific research to reveal the therapeutic properties of this plant against two human breast cancer cell lines, MCF-7 and MDA-MB-231. We hypothesized that FAA extract induces anticancer effects through the induction of cell cycle arrest and apoptosis in human breast cancer cells. Based on this hypothesis, the study aimed to investigate the possible mechanisms of action in MCF-7 and MDA-MB-231 cells.

\section{Materials and Methods}

2.1. Preparation of Plant Extract. The process of extract preparation was described previously [10]. Fresh flowers of A. atroviolaceum were collected in July of 2013 from Kojur, Iran (latitude $=36.3825$, longitude $=51.7106$, Lat $=36$ degrees, 23.0 minutes north, Long $=51$ degrees, 42.6 minutes east). The plant was compared with the voucher specimen number 720-722 deposited at the Faculty of Biology Herbarium, Azad University of Ghaemshahr, Iran. Harvested fresh flowers were rinsed and air dried at room temperature. The dried material was homogenized to obtain a coarse powder and extracted by $70 \%$ methanol (CheMarCo Inc., SC, USA) for $6 \mathrm{~h}$, using Soxhlet apparatus (Electrothermal Eng., Rochford, UK). The extract was concentrated in a rotary evaporator (Büchi Labortechnik AG, Flawil, Switzerland). The resultant condensate was subjected to freeze-drying (VirTis ${ }^{\circledR}$ BenchTop $^{\mathrm{TM}} \mathrm{K}$ freeze dryer, NY, USA). The stock solution of extract was prepared by dimethyl sulfoxide (DMSO) (Sigma-Aldrich, MO, USA) prior to usage.

2.2. Cell Lines. The human breast cancer cell lines, MCF7 (human hormone-dependent breast cancer cell line; ATCC HTB-22) and MDA-MB-231 (human non-hormonedependent breast cancer cell line; ATCC HTB-26), and the normal 3T3 cell line (mouse embryo fibroblast; ATCC CRL-1658) were purchased from American Type Culture Collection (VA, USA). Cell lines were grown in tissue culture flasks at $37^{\circ} \mathrm{C}, 5 \% \mathrm{CO}_{2}$, and $90 \%$ humidity (IR censored $\mathrm{CO}_{2}$ incubator) in RPMI-1640 medium (Sigma-Aldrich, Steinheim, Germany), containing 10\% fetal bovine serum (Sigma-Aldrich, Steinheim, Germany) and $100 \mathrm{IU} / \mathrm{ml}$ penicillin streptomycin (Sigma-Aldrich, Steinheim, Germany). The cells were grown confluence, which could be observed under an inverted microscope and subcultured at three to four days interval.

2.3. MTT Cell Proliferation Test. The antiproliferative effects of FAA on MCF-7 and MDA-MB-231 cells were examined using the MTT colorimetric assay. Cells were seeded in 96well plates (TPP, Switzerland) at a density of $10^{6}$ cells $/ \mathrm{ml}$ for $24 \mathrm{~h}$ before exposure to the indicated concentrations of FAA for 24,48 , and $72 \mathrm{~h}$. Media without FAA extract were used as a negative control. After removal of the medium, $20 \mu \mathrm{l}$ of MTT reagent (Sigma-Aldrich, MO, USA) was added to each well and followed by $4 \mathrm{~h}$ incubation. The purple formazan crystals were dissolved in $100 \mu \mathrm{l}$ of DMSO. The optical density (OD) of each well was measured at $570 \mathrm{~nm}$ on FLUOstar Omega microplate reader (BMG Labtech, Ortenberg, Germany). An experiment was done in triplicate and cell viability has been calculated by following equation:

$$
\% \text { Cytotoxicity }=\frac{\mathrm{OD} \text { of treated cells }}{\mathrm{OD} \text { of negative control }} \times 100 \text {. }
$$

2.4. Microscopic Examination. To determine the effects of FAA on the cell morphology, the cells were seeded in 6well plates $\left(10^{6} / \mathrm{ml}\right)$. After $24 \mathrm{~h}, 5 \mathrm{ml}$ of media containing $\mathrm{IC}_{50}$ concentrations of the FAA was added, while the control contained untreated media. After 24, 48, and $72 \mathrm{~h}$, the cells were then washed with PBS and observed by Olympus Culture Microscope, model CK40 (Olympus Corporation, Tokyo, Japan).

Moreover, acridine orange $(\mathrm{AO})$ and propidium iodide (PI) double staining was applied to observe the apoptotic feature of the cells by fluorescent microscope. MCF-7 and MDA-MB-231 cells were seeded at density of $5 \times 10^{6}$ cells/well and incubated for $24 \mathrm{~h}$; then the medium was replaced with $\mathrm{IC}_{50}$ concentration of FAA dissolved in the medium and the cells were incubated for 24,48 , and $72 \mathrm{~h}$. The cell suspension was mixed with an equal volume of AO/PI (Sigma-Aldrich, MO, USA) staining solution ( $1: 1)$. The viable, apoptotic, and necrotic cells were observed under Leica fluorescence microscope DM 2500 (Leica Microsystem, Wetzlar, Germany) within $30 \mathrm{~min}$ with $100 \mathrm{x}$ magnification. Images were captured by using Alpha Imager (Alpha Innotech, CA, USA).

2.5. Flow Cytometric Cell Cycle Analysis. The effect of FAA on MCF-7 and MDA-MB-231 cell cycle distribution was determined by flow cytometric analysis. Cells were seeded at density of $5 \times 10^{6}$, cultured for $24 \mathrm{~h}$ prior to treatment with $\mathrm{IC}_{25}, \mathrm{IC}_{50}$, and $\mathrm{IC}_{75}$ concentrations of FAA exposure for 24,48 , and $72 \mathrm{~h}$. The cells were then resuspended in $500 \mu \mathrm{l}$ PBS prior to being fixed at $70 \%$ cold ethanol for at least $2 \mathrm{~h}$ at $-20^{\circ} \mathrm{C}$. After centrifuging at $1000 \mathrm{rpm}$ for 10 minutes and washing twice with PBS, the fixed cells were treated with $500 \mu \mathrm{l} \mathrm{PI} / \mathrm{RNase}(400 \mu \mathrm{l}$ propidium iodide and $100 \mu \mathrm{l}$ Ribonuclease A) and incubated for $10 \mathrm{~min}$ at room temperature. The DNA content per cell was analysed using BD LSRFortessa ${ }^{\mathrm{TM}}$ Cell Analyzer (Becton Dickinson, NJ, USA), equipped with $488 \mathrm{~nm}$ argon laser light source and $630 \mathrm{~nm}$ band pass filter for 10,000 events per sample. Data was expressed as percentage of cells compared to untreated 
control population, using along with its analytical software BD FACSDiva $^{\mathrm{TM}}$ software.

2.6. Annexin-V-FITC/PI. Apoptotic and necrotic cells were differentiated using the Annexin assay V-FITC kit (SigmaAldrich, MO, USA) as per the manufacturer's protocol. Cells were plated at $5 \times 10^{6}$ and incubated for $24 \mathrm{~h}$ prior to the indication by $\mathrm{IC}_{25}, \mathrm{IC}_{50}$, and $\mathrm{IC}_{75}$ concentrations of FAA exposure for 24,48 and $72 \mathrm{~h}$. The cells were centrifuged (1000 rpm for 5 minutes), resuspended in 1x Annexin-V binding buffer, and stained with $10 \mu \mathrm{l}$ of PI and $5 \mu \mathrm{l}$ of Annexin-V-FITC for $10 \mathrm{~min}$ in darkness, prior to analyis by flow cytometry. For each experiment 10,000 events per sample were recorded.

2.7. Assay of Caspase Activity. Caspase colorimetric protease assay sample kit (Biovision, CA, USA) was used to determine the activity of caspases $1,2,3,-5,6,8$, and 9 . Cells $\left(10^{6} / \mathrm{ml}\right)$ were seeded in 6-well plate and incubated for $24 \mathrm{~h}$, prior to exposure to FAA in various concentrations. The cells were then transferred into sterile test tube and lysed using the cell lysis buffer and incubated on ice for $10 \mathrm{~min}$. After centrifugation at $5000 \mathrm{rpm}$ for $2 \mathrm{~min}$, samples $(50 \mu \mathrm{l})$ of the lysate were aliquoted into a 96-well microplate, to which $50 \mu \mathrm{l}$ of reaction buffer containing $10 \mathrm{Mm}$ DTT was then added to the sample. Substrates for each of the caspases ( $5 \mu \mathrm{l})$ were added to the appropriate wells and the plate was then incubated for $2 \mathrm{~h}$. Absorbance at $405 \mathrm{~nm}$ was then read in a microplate reader. The absorbance of treated samples was compared with untreated control. The selective substrates used were $\mathrm{p}$-nitroaniline.

2.8. qPCR Analysis of Cell Cycle and Apoptosis Responsive Genes. Gene's expression was analysed with quantitative reverse transcription-PCR using a real-time SYBR Green gene expression assay kit as described in the protocol. Total RNA was isolated from the MCF-7 and MDA-MB-231 cells, treated with $\mathrm{IC}_{25}, \mathrm{IC}_{50}$, and $\mathrm{IC}_{75}$ concentration of FAA for $24 \mathrm{~h}$ using RNeasy Mini kit (Qiagen Inc., CA, USA). RNA samples were quantitated at OD $260 / 280$ by NanoDrop Spectrophotometer along with its analytical software V3.7 (Thermo Fisher Scientific, DE, USA) and RIN number was determined by Bioanalyzer (Agilent 2100 Bioanalyzer $^{\mathrm{TM}}$ system-Agilent Technologies, Waldbronn, Germany). The RNA $(1 \mu \mathrm{g})$ was introduced to reverse transcription with RT2 first strand kit (Qiagen Inc., CA, USA) and the cDNA were analysed using RT2 SYBR ${ }^{\circledR}$ Green ROX $^{\mathrm{TM}}$ FAST Mastermix (Qiagen Inc., CA, USA). qPCR was performed in a reaction volume of $25 \mu \mathrm{L}$ as per the manufacturer's instructions. Briefly, $12.5 \mu \mathrm{L}$ of RT2 SYBR ${ }^{\circledR}$ Green Mastermix, $1 \mu \mathrm{L}$ of assay primers (RT2 ${ }^{2}$ qPCR Primer Assays, Qiagen Inc., CA, USA), and $1 \mu \mathrm{L}$ of template $\mathrm{CDNA}$ were added to each well. The PCR plate was placed in the real-time PCR instrument, Corbett Rotor-Gene 6000 (Qiagen Inc., CA, USA), and run at $95^{\circ} \mathrm{C}$ for 10 minutes (activating the enzyme) and 40 cycles of 15 seconds at $95^{\circ} \mathrm{C}$ (denaturation) followed by 30 seconds at $60^{\circ} \mathrm{C}$ (annealing and synthesis). The expression levels were expressed as $n$-fold differences relative to the reference gene,
GAPDH. The data were analysed using a comparative threshold $(\mathrm{Ct})$ method, and the fold inductions of samples were compared with the untreated samples. The gene expression level was then calculated by following formula:

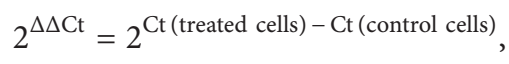

where 2 is the amplification efficiency where the template doubles in each cycle during exponential amplification.

The following primer pairs for target genes and GAPDH were chosen from the Primer Bank website: $B c l-2: 5^{\prime}$-TAC CTG AAC CGG CAC CTG- $3^{\prime}$ and $5^{\prime}$ - GCC GTA CAG TTC CAC AAA GG-3'; Cdk1: 5'- GGGTCAGCTCGCTACTCAAC- $3^{\prime}$ and $5^{\prime}$-AAGTTTTTGACGTGGGATGC$3^{\prime}$; $p 53: 5^{\prime}$ - TGT GGA GTA TTT GGA TGA CA- $3^{\prime}$ and $5^{\prime}$ - GAA CAT GAG TTT TTT ATG GC-3'; GAPDH: $5^{\prime}$ TCCTGCACCA CCAACTGCTTAG- $3^{\prime}$ and $5^{\prime}$ - GGCATGGACTGTGG TCATGAGT-3'.

2.9. Evaluation of TAM and FAA Combination Effect. To assess the synergistic effect of FAA extracts in combination with TAM, the cells were seeded at $1 \times 10^{6} \mathrm{cells} / \mathrm{ml}$ and incubated for $24 \mathrm{~h}$. After incubation, the cells were treated with combination of $\mathrm{IC}_{50}$ values of FAA and TAM (obtained in our previous study [9]) and incubated for an additional 24,48 , and $72 \mathrm{~h}$. The MTT solution $(20 \mu \mathrm{l})$ was added to each well and incubated for $4 \mathrm{~h}$. The MTT-formazan crystals formed were dissolved in $100 \mu \mathrm{l}$ of DMSO and the absorbance was measured at $550 \mathrm{~nm}$. The $\mathrm{IC}_{50}$ obtained for single-agents were compared to the $\mathrm{IC}_{50}$ calculated for their combination. The combination index (CI) was calculated by CompuSyn software (Paramus, NJ, USA) to analyse synergistic inhibitory effect. The CI values $<1,=1$, and $>1$ represent a synergistic, additive, and antagonistic effects, respectively [12].

2.10. Liquid Chromatography-Mass Spectrometry (LC-MS). LC-MS was used to identify the major compounds in the FAA extract. Chromatographic analysis of FAA was carried out by reverse phase elution (Waters Symmetry LC18 column $250 \times 4.6 \mathrm{~mm}, 5 \mu \mathrm{m})$ on Agilent 6500 Series Accurate-Mass Quadrupole Time-of-Flight (Q-TOF; Agilent Santa Clara, CA, USA) LC/MS system with Agilent 1200 Series Diode Array Detector (module G1315B; detection type: 1024-element photodiode array; light source: deuterium and tungsten lamps; wavelength range $190-950 \mathrm{~nm})$. The mobile phase consisted of (A) formic acid $(0.1 \%, v / v)$; (B) acetonitrile $+0.1 \%$ formic acid; gradient (in solvent B): (i) $20 \%$, from 0 to $20 \mathrm{~min}$, (ii) $95 \%$, from 20 to $27 \mathrm{~min}$, and (iii) $35 \%$, at $27-30 \mathrm{~min}$ of total run time; flow rate: $0.2 \mathrm{ml} / \mathrm{min}$; injection volume $3 \mathrm{~L}$; ESI parameters: both negative and positive ion mode; mass range $100-1200 \mathrm{~m} / z$; spray voltage $4 \mathrm{kV}$; gas temperature $325^{\circ} \mathrm{C}$; gas flow $10 \mathrm{~L} / \mathrm{min}$; Nebulizer $40 \mathrm{psi}$ and the mass was analysed by using Agilent technologies MassHunter software.

2.11. Statistical Analysis. Results were analysed by version 7 of GraphPad Prism, using one-way analysis of variance (ANOVA), and differences were considered statistically significant at the level of $p$ values $\leq 0.05,0.01$, and 0.001 . Gene 


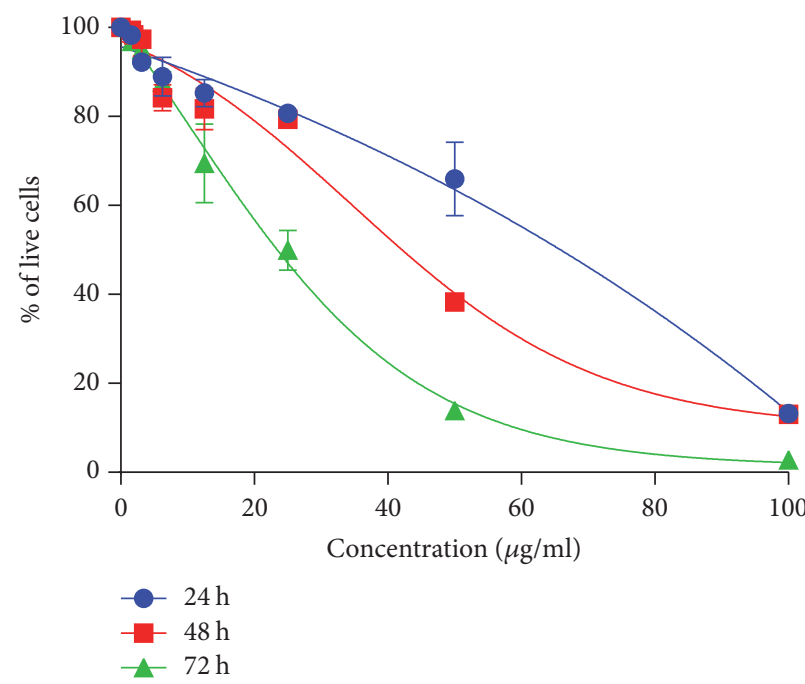

(a)

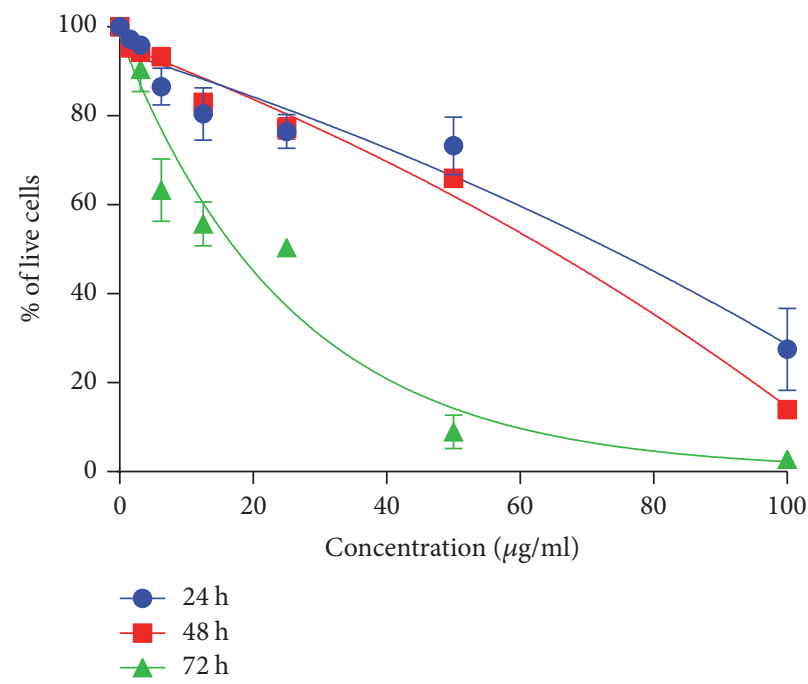

(b)

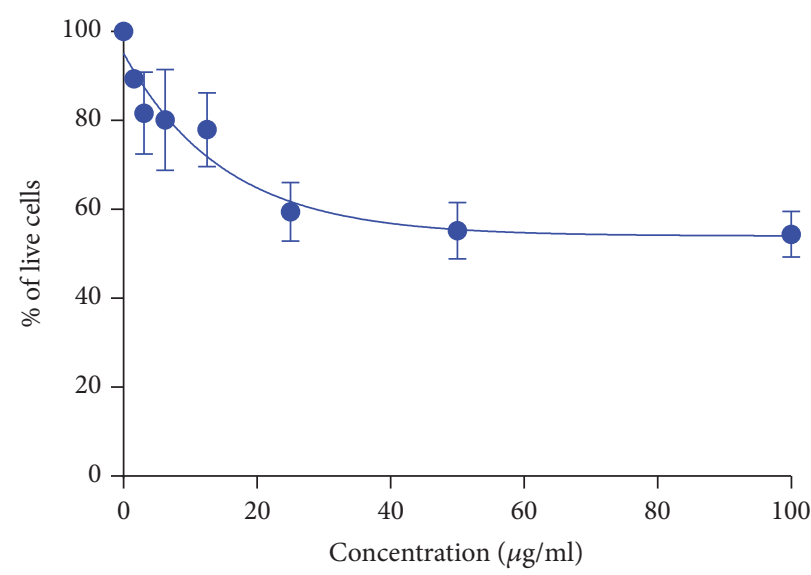

(c)

FIGURE 1: Antiproliferative effect of FAA on breast cancer and 3 T3 cells. Dose-response curves of FAA treatment on MCF-7 (a), MDA-MB-231 (b), and 3T3 (c) [10]. Data represent the mean \pm SD of three independent experiments.

expression analysis was done using Student's $t$-test and the differences were considered statistically significant at the level of $p$ values $\leq 0.05$.

\section{Results}

3.1. Cell Proliferation Inhibition after FAA Treatment. The proliferation of MCF-7 and MDA-MB-231 cells, treated with various concentrations of FAA, was significantly inhibited in a dose- and time-dependent manner. The estimated $\mathrm{IC}_{50}$ value was $65.5 \pm 9 \mu \mathrm{g} / \mathrm{ml}, 41 \pm 0 \mu \mathrm{g} / \mathrm{ml}$, and $24.67 \pm 3.5 \mu \mathrm{g} / \mathrm{ml}$ in the case of MCF-7 (Figure $1(\mathrm{a})$ ) and $77 \pm 5.29 \mu \mathrm{g} / \mathrm{ml}, 67$ $\pm 0 \mu \mathrm{g} / \mathrm{ml}$, and $51 \pm 1.7 \mu \mathrm{g} / \mathrm{ml}$ for MDA-MB-231 cell lines (Figure 1(b)) after 24, 48, and $72 \mathrm{~h}$, respectively. However, based on our previous study FAA showed no evident cytotoxicity against the healthy mouse fibroblast 3T3 cells after $72 \mathrm{~h}$ (Figure 1(c)) [10].

3.2. Morphological Feature of Apoptosis. The morphological appearances of MCF-7 and MDA-MB-231 after 24, 48, and
$72 \mathrm{~h}$ of exposure to FAA were observed under the inverted light microscope. In the case of untreated cells, high density of monolayer cells with intact membrane was observed. However, the cells showed morphological changes such as autophagy and reduction in the cell volume after the treatment with $\mathrm{IC}_{50}$ concentration of FAA extracts at $24 \mathrm{~h}$. The features of apoptosis were clearly observed after $48 \mathrm{~h}$ of treatment, where the treated cells showed the formation of shrinking, membrane blebbing, and membrane bounded vesicles (apoptotic bodies). The extracts showed more cytotoxic effects after $72 \mathrm{~h}$ of incubation, since only debris was present in the culture.

The morphological changes in the cancer cells nuclei were observed by fluorescence microscope to understand the mode of cell death. AO and PI were used to differentiate between viable, apoptotic, and necrotic cell, based on membrane integrity. The results revealed that FAA triggered morphological features that relate to apoptosis in a timedependent manner. The untreated cells showed an intact round nuclear membrane with the nuclei heavily stained by 


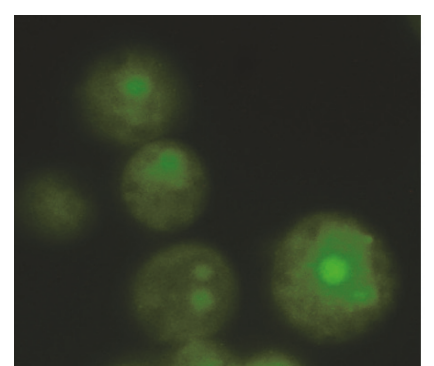

(a1)

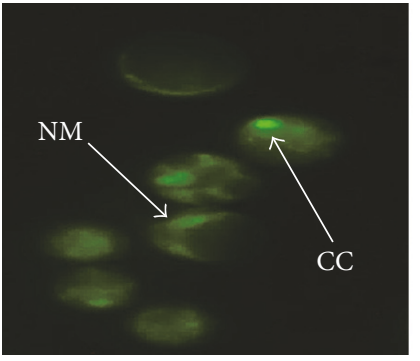

(a2)

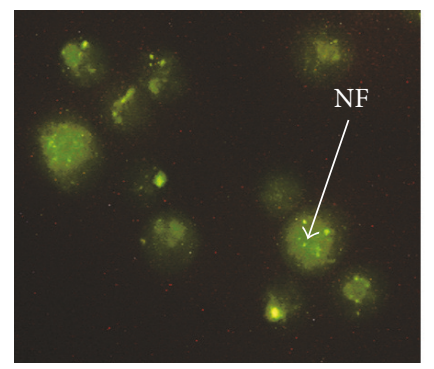

(a3)

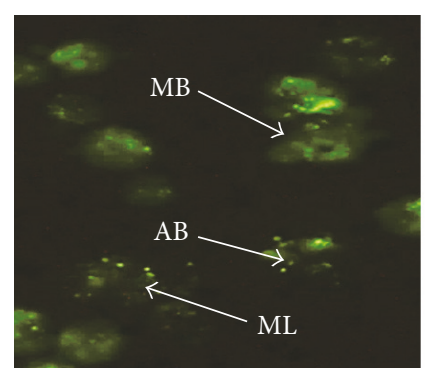

(a4)

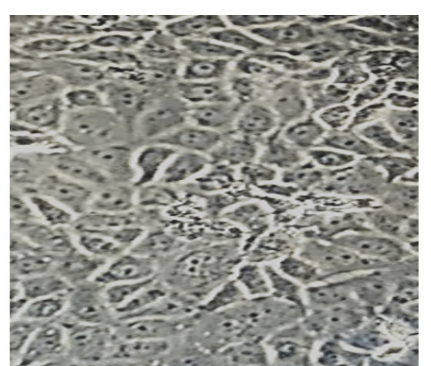

$\left(\mathrm{a} 1^{\prime}\right)$

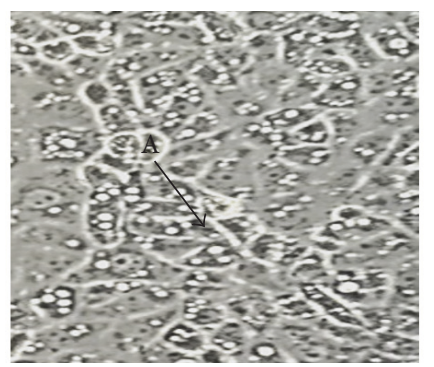

$\left(\mathrm{a} 2^{\prime}\right)$

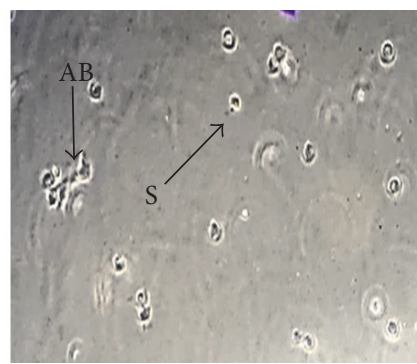

$\left(\mathrm{a} 3^{\prime}\right)$

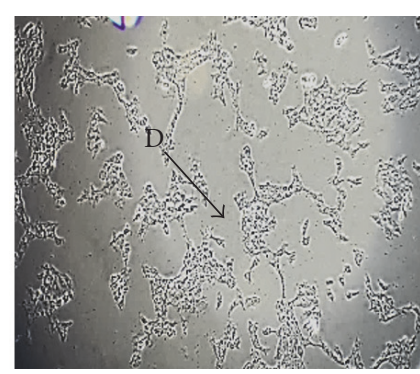

$\left(\mathrm{a} 4^{\prime}\right)$

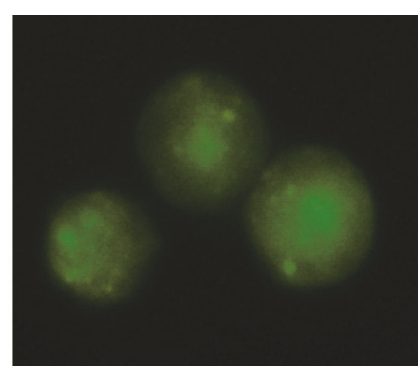

(b1)

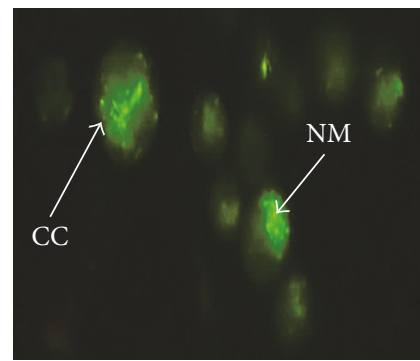

(b2)

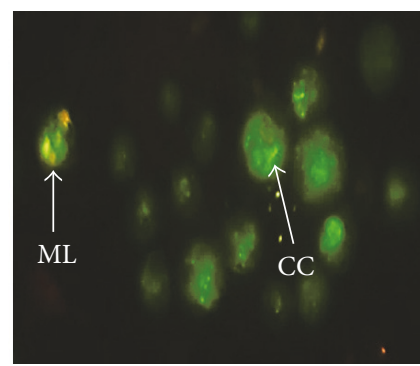

(b3)

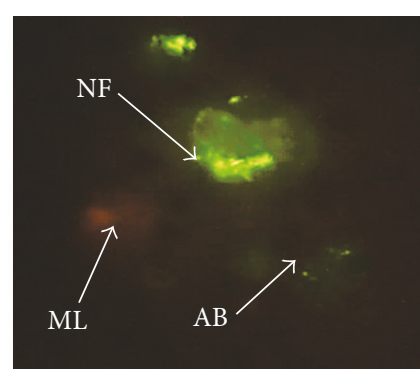

(b4)

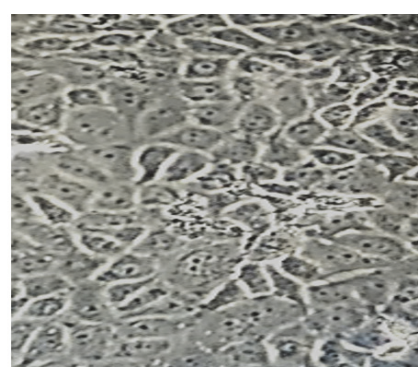

$\left(\mathrm{b} 1^{\prime}\right)$

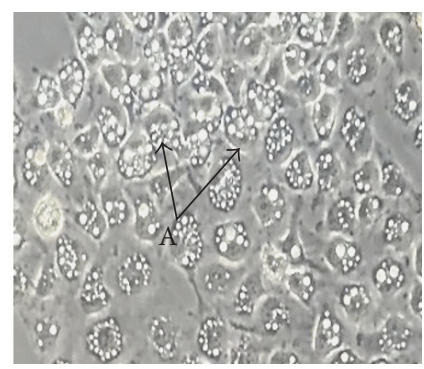

(b2')

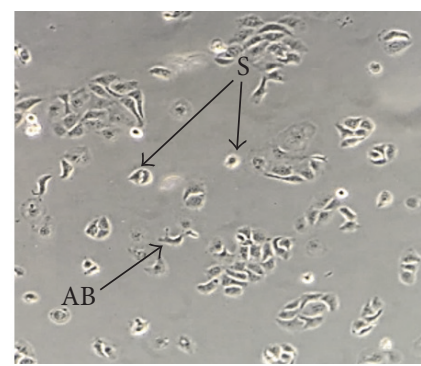

(b3')

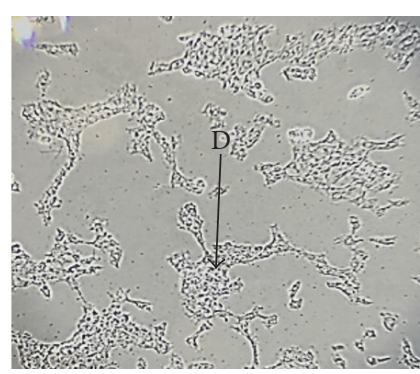

(b4 ${ }^{\prime}$ )

FIGURE 2: Morphological observation of treated MCF7 and MDA-MB-231 cells by phase contrast and fluorescence microscopy. (a1)-(a4) and $\left(\mathrm{al}^{\prime}\right)-\left(\mathrm{a} 4^{\prime}\right)$ indicate the untreated and treated MCF7 cells with FAA for $24 \mathrm{~h}, 48 \mathrm{~h}$, and $72 \mathrm{~h}$, respectively, while (b1)-(b4) and (b1')-(b4') display the untreated and treated MDA-MB-231 cells with FAA for $24 \mathrm{~h}, 48 \mathrm{~h}$, and $72 \mathrm{~h}$, respectively. In phase contrast images autophagy (A), shrinkage (S), apoptotic bodies (AB), and debris (D) are shown. In fluorescent images the typical characteristics of apoptosis such as nuclear margination (NM), chromatin condensation (CC), nuclear fragmentation (NF), membrane blebbing (MB), apoptotic bodies (AB), and membrane looseness (ML) are presented. Similar cellular morphology was observed in three independent experiments $(n=3)$.

AO green fluorescence. After the treatment of MCF-7 with FAA at $24 \mathrm{~h}$, the cell showed typical morphological features of apoptosis, including nuclear margination and chromatin condensation. After $48 \mathrm{~h}$, granulation in the nucleus was clearly observed. The treatment at $72 \mathrm{~h}$ with FAA showed membrane blebbing, apoptotic bodies, and membrane looseness. Moreover, similarly to MCF-7, MDA-MB-231 cells exhibited nuclear margination and chromatin condensation, which were major consequences of the apoptotic trigger, after the treatment with FAA at $24 \mathrm{~h}$, while the 48 and $72 \mathrm{~h}$ of treatments represented both early (chromatin condensation, nuclear fragmentation) and late apoptosis (apoptotic bodies, membrane looseness) features (Figure 2).

3.3. Cell Cycle Arrest in MCF-7 and MDA-MB-231 Cells. The DNA content was measured by flow cytometry to evaluate 


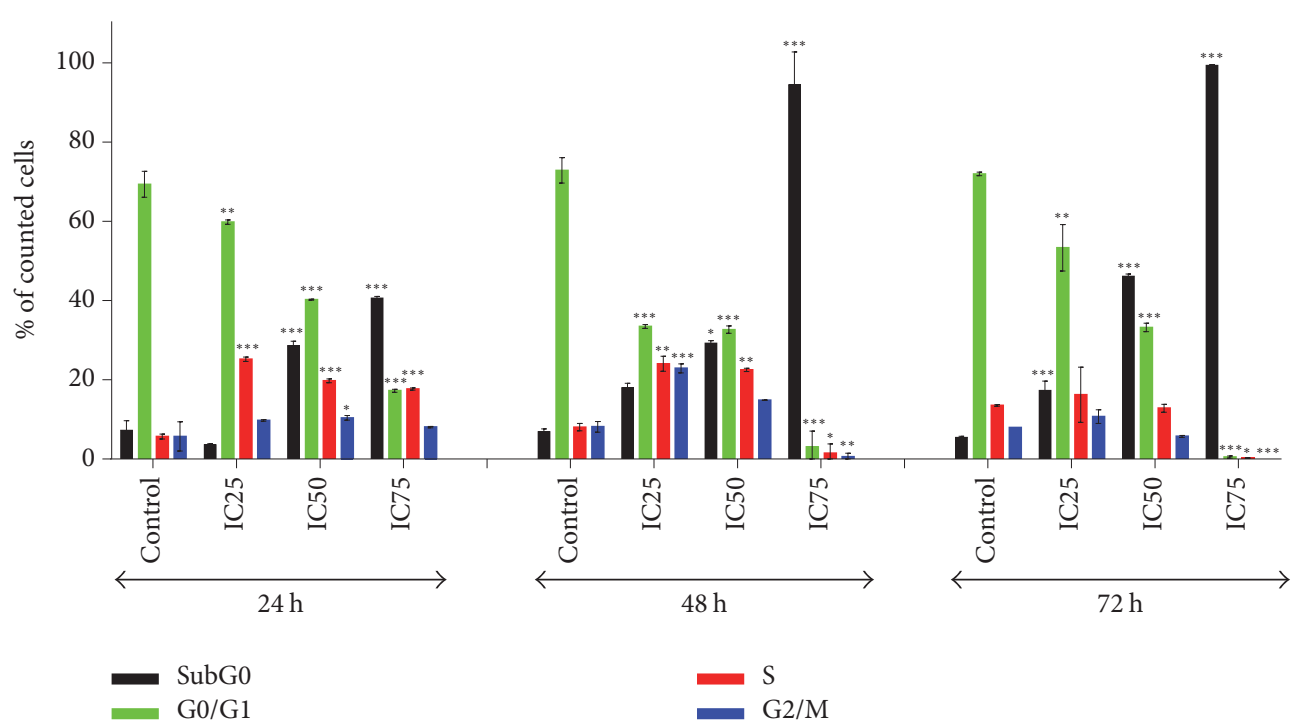

(a)

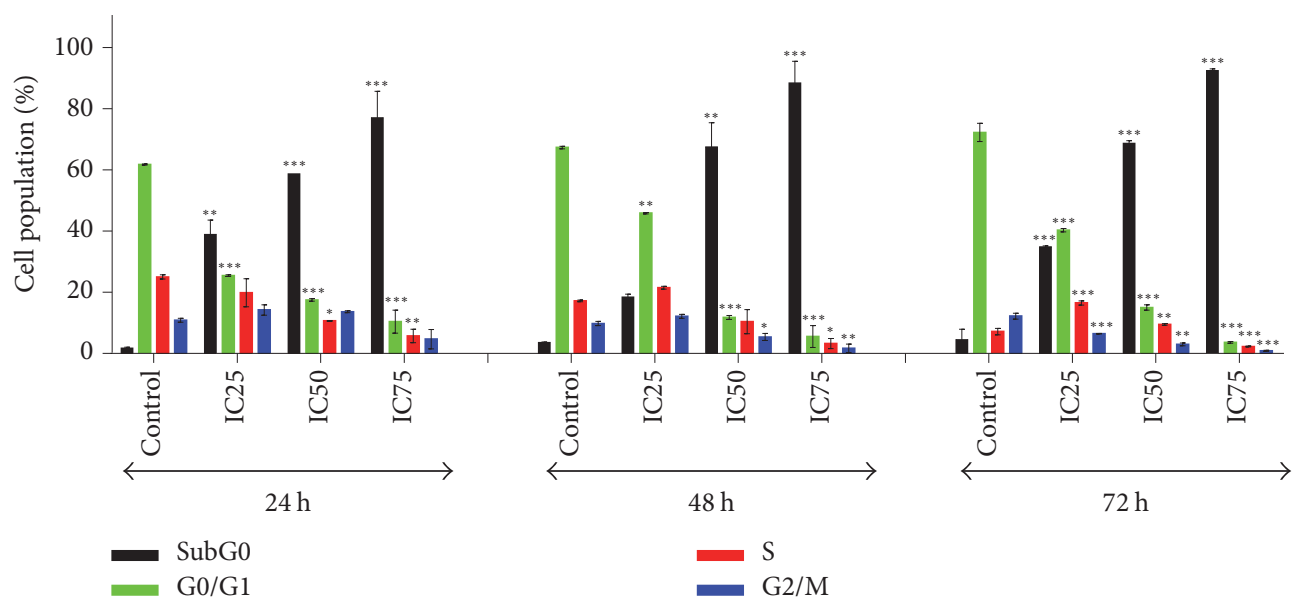

(b)

Figure 3: Cell cycle analysis of MCF7 and MDA-MB-231 cancer cells treated with FAA at IC25, IC50, and IC75 values. The distribution of (a) MCF7 and (b) MDA-MB-231 cells undergoing apoptosis and in various phases of the cell cycle was determined for 24, 48, and 72 $\mathrm{h}$ in comparison to the respective controls. The values are presented as mean \pm standard error of mean of three determinations, indicated by $*$, $* *$, and $* * *$, showing a significant difference $(p<0.05, p<0.01$, and $p<0.001$, resp. $)$.

the cell cycle distribution of MCF-7 and MDA-MB-231 cells with or without FAA treatment. Treatment of MCF7 presented a subcellular peak and a dramatic decrease in $\mathrm{G}_{0} / \mathrm{G}_{1}$ phase in a dose- and time-dependent manner. At $24 \mathrm{~h}$, distribution of cells in the $S$ phase significantly increments in treated cells with $\mathrm{IC}_{25}, \mathrm{IC}_{50}$, and $\mathrm{IC}_{75}$ of FAA, while, after $48 \mathrm{~h}$, this value is considerably increased by $\mathrm{IC}_{25}$ and $\mathrm{IC}_{50}$ concentrations of FAA. However, the $72 \mathrm{~h}$ treatment increased the $S$ phase percentage only in $\mathrm{IC}_{25}$ (Figure 3(a), see Figure SI in Supplementary Material available online at https://doi.org/10.1155/2017/1468957). Moreover, $24 \mathrm{~h}$ treatment by $\mathrm{IC}_{25}, \mathrm{IC}_{50}$, and $\mathrm{IC}_{75}$ of FAA represented a significant enhance of MDA-MB-231 cell distribution at $\mathrm{G}_{2} / \mathrm{M}$ phase. Though, $48 \mathrm{~h}$ treatment increased this value by $\mathrm{IC}_{25}$ and $\mathrm{IC}_{50}$ values of FAA. The event occurred after $72 \mathrm{~h}$ of treatment with $\mathrm{IC}_{25}$ and $\mathrm{IC}_{50}$ of FAA, when the cells were accumulated at the $S$ phase, accompanied by a large enhancement of sub- $\mathrm{G}_{0}$ and remarkable reduction of $G_{0} / G_{1}$ phase in a time and dose course manner (Figures 3(b), SII).

3.4. Induction of Apoptosis in MCF-7 and MDA-MB-231. To determine the effect of FAA in apoptosis induction, the FITCAnnexin-V staining was used through flow cytometry. The percentages of live cell significantly declined in both cell lines, after the treatment with FAA in a dose-dependent manner. Analysis of MCF-7 cells showed variation in apoptotic and necrotic cell percentage in time- and dose-dependent manner. The percentage of early apoptotic cells increased after $24 \mathrm{~h}$ by $\mathrm{IC}_{25}, \mathrm{IC}_{50}$, and $\mathrm{IC}_{75}$, with $\mathrm{IC}_{50}$ and $\mathrm{IC}_{75}$ values after $48 \mathrm{~h}$ and with $\mathrm{IC}_{50}$ and $\mathrm{IC}_{75}$ of FAA after $72 \mathrm{~h}$. Meanwhile, late apoptosis increased markedly in cells treated with $\mathrm{IC}_{50}$ after $24 \mathrm{~h}$, with $\mathrm{IC}_{75}$ after $48 \mathrm{~h}$ and with $\mathrm{IC}_{25}, \mathrm{IC}_{50}$, and $\mathrm{IC}_{75}$ after 


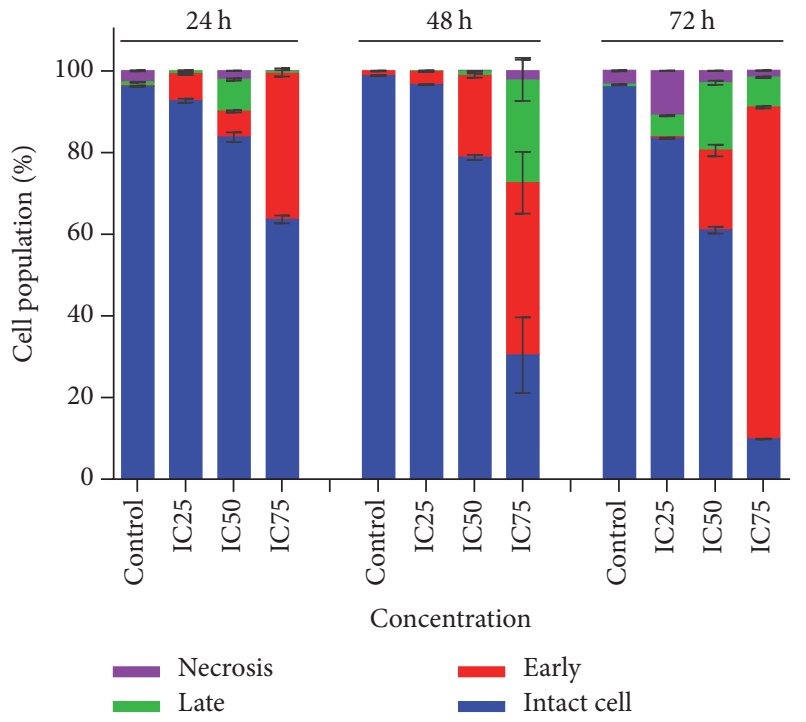

(a)

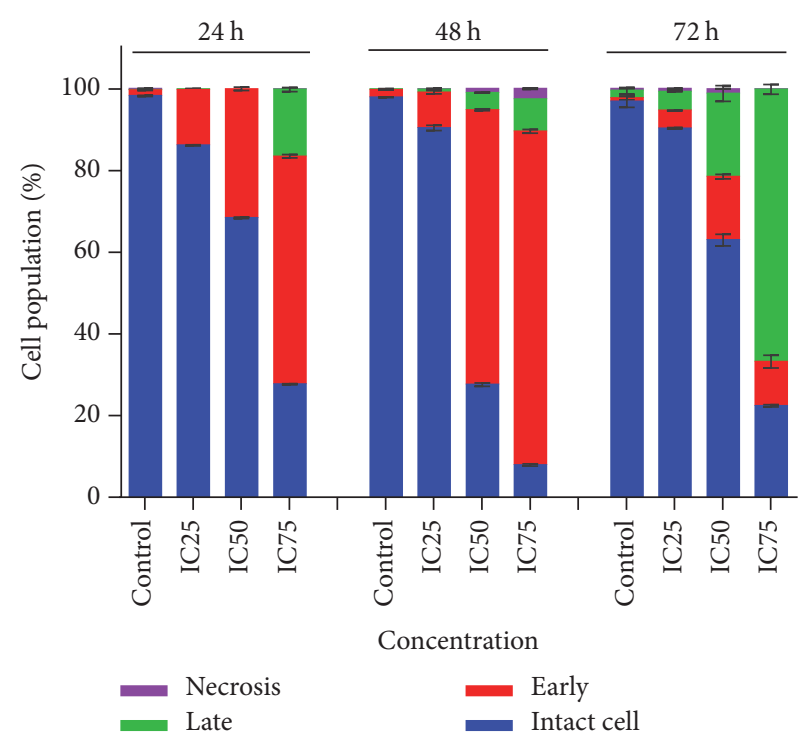

(b)

Figure 4: Apoptosis study of MCF-7 and MDA-MB-231 cells exposed to FAA extract at IC25, IC50, and IC75 values. The distribution of live cells and cells undergoing early apoptosis, late apoptosis, and necrosis was determined in (a) MCF7 and (b) MDA-MB-231 cells following treatment with FAA for 24, 48, and $72 \mathrm{~h}$ in comparison to the respective control, using Annexin-V-FITC and propidium iodide flow cytometric analysis. The values are presented as mean \pm standard error of mean of three determinations.

$72 \mathrm{~h}$. In contrast, the percentages of cells entering necrosis decreased with $\mathrm{IC}_{25}$ and $\mathrm{IC}_{75}$ of FAA after $24 \mathrm{~h}$ and with $\mathrm{IC}_{50}$ and $\mathrm{IC}_{75}$ after $72 \mathrm{~h}$. No reportable change in the percentage of necrotic cells was observed after the treatment with FAA for $48 \mathrm{~h}$ (Figure 4(a)).

The proportion of early apoptotic MDA-MB-23 cells enhanced after $24 \mathrm{~h}, 48 \mathrm{~h}$, and $72 \mathrm{~h}$ with $\mathrm{IC}_{25}, \mathrm{IC}_{50}$, and $\mathrm{IC}_{75}$ concentrations of FAA. On the other hand, the cell proportion in late apoptosis was significantly raised in cells treated with $\mathrm{IC}_{75}$ of FAA after $24 \mathrm{~h}, 48 \mathrm{~h}$, and $72 \mathrm{~h}$ with $\mathrm{IC}_{25}$, $\mathrm{IC}_{50}$ and $\mathrm{IC}_{75}$. Percentages of cells entering necrosis were significantly enhanced only after $48 \mathrm{~h}$ in cells treated with $\mathrm{IC}_{50}$ and $\mathrm{IC}_{75}$ of FAA (Figure 4(b)).

3.5. FAA Treatment Activates the Caspases. The activation of two inflammatory caspases (caspases 1 and 5), three initiator caspases (caspases 2, 8, and 9), and two executioner caspase (caspases 3 and 6) was investigated at three concentrations of FAA extract in $24 \mathrm{~h}$. Caspase-1 activity in both treated cells resulted in a significant reduction, compared to the untreated cells. The FAA treatment was found to decrease the activity of caspase- 5 in MCF-7, while in MDA-MB-231 cells it increased at $\mathrm{IC}_{25}$ of FAA. The induction of caspase- 2 activity increased significantly in MDA-MB-231, but not in MCF7. The level of caspase- 9 was evaluated significantly at $\mathrm{IC}_{75}$ of FAA in MCF-7. In contrast, MDA-MB-231 cells exposed to low concentration $\left(\mathrm{IC}_{25}\right)$ of FAA exhibited a significantly higher activation compared to the control. FAA could trigger caspase- 8 activity in both MCF-7 and MDA-MB-231 cell lines in $\mathrm{IC}_{50}$ and $\mathrm{IC}_{75}$ concentrations. Since both upstream signalling pathways (intrinsic and extrinsic pathway) converge downstream to activate the final effector caspase mechanism, the activity of caspase- 3 and caspase- 6 executioner caspases was investigated. The results demonstrated that FAA sharply induced caspase- 6 activity in MCF-7 cells, as the activity significantly increased in all used concentrations. On the other hand, caspase- 6 activity was also enhanced with $\mathrm{IC}_{50}$ of FAA in the MDA-MB-231. The FAA extract was found to increase the activity of caspase-3 significantly only in MCF-7 cell line in $\mathrm{IC}_{25}$ value (Figure 5).

3.6. Expression Levels of Bcl-2, Cdk1, and p53 in MCF-7 and MDA-MB-231 Cells. The effects of $\mathrm{IC}_{25}, \mathrm{IC}_{50}$, and $\mathrm{IC}_{75}$ value of FAA extract at $24 \mathrm{~h}$ on $B c l-2, C d k 1$, and $p 53$ gene modulation were investigated by $\mathrm{qRT}-\mathrm{PCR}$. The extracted RNA from all the samples exhibited high quality and purity. The expression of $\mathrm{Bcl}-2$ gene in the treated MCF-7 cells was found to be dramatically downregulated by 2.18 -fold and 4.9fold, after treatment with $\mathrm{IC}_{50}$ and $\mathrm{IC}_{75}$ value. In MDA-MB231 cells a significant downregulation of $\mathrm{Bcl}-2$ gene expression occurred after the treatment with $\mathrm{IC}_{75}$ of FAA by 2.15 -fold, when compared to the untreated cells. The treatment of MCF7 cells with $\mathrm{IC}_{75}$ remarkably downregulated the $C d k 1$ gene expression with 5.77-fold. Moreover, the mRNA level of $C d k 1$ in MDA-MB revealed a 3.33 -fold downregulation at $\mathrm{IC}_{75}$ concentration, compared to the control. However, $p 53$ gene expression was found to be nonsignificant in both cell lines (Figure 6).

3.7. Combination Effect of FAA and Tamoxifen in MCF-7 and $M D A-M B-231$ Cells. Based on the data showing efficacy of FAA in breast carcinoma cells, next we assessed the combinations effect of FAA and tamoxifen (TAM) on MCF7 and MDA-MB cell growth. According to our previous 

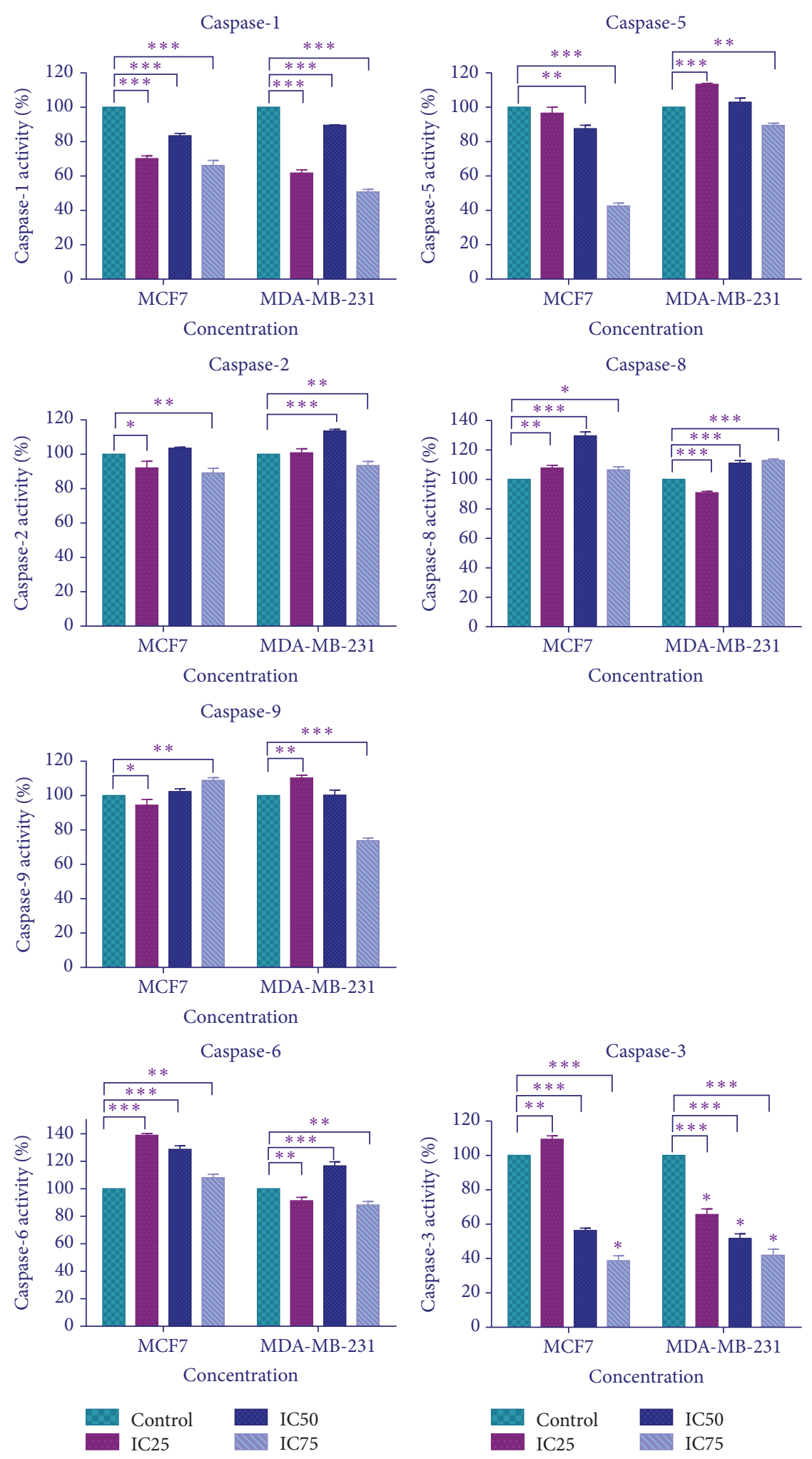

Figure 5: Activation of caspases by FAA in MCF-7 and MDA-MB-231 cells. The cells were incubated with FAA extract at IC25, IC50, and IC75 values for $24 \mathrm{~h}$, after which the activity of various caspases was determined as described in Section 2 . Data are presented in mean $\pm \operatorname{SD}(n=3)$. Values for the treated group are significantly different to the untreated control group at the same time point at ${ }^{*} p<0.05,{ }^{* *} p<0.01$, and ${ }^{* * *} p<0.001$. 

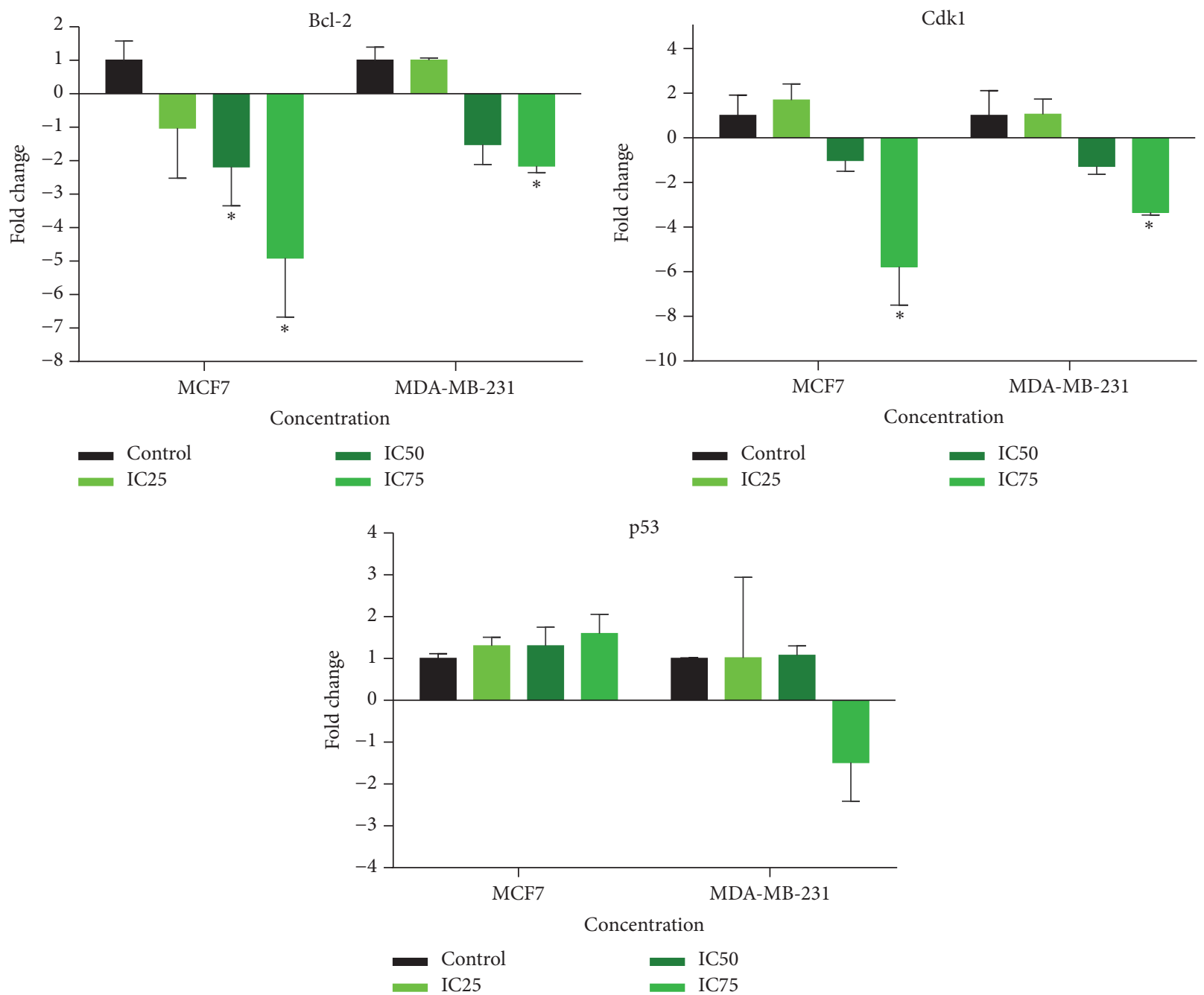

Figure 6: The expression of Bcl2, Cdk1, and $p 53$ in MCF7 and MDA-MB-231 by real-time quantitative PCR analysis. After treatment with the IC25, IC50, and IC75 of FAA for $24 \mathrm{~h}$, the relative quantification of the target gene by the delta-delta-Ct method was done using the Qiagen software. Values for the treated group are significantly different to the untreated control group at ${ }^{*} p \leq 0.05$.

study, treatment of the cells with a serial dilution of TAM, as a positive control, indicated the $\mathrm{IC}_{50}$ value of $9.8 \mu \mathrm{g} / \mathrm{ml}$, $7.2 \mu \mathrm{g} / \mathrm{ml}$, and $6.7 \mu \mathrm{g} / \mathrm{ml}$ for MCF-7 and $13.6 \mu \mathrm{g} / \mathrm{ml}$ and $11 \mu \mathrm{g} / \mathrm{ml}$ and $3.78 \mu \mathrm{g} / \mathrm{ml}$ for MDA-MB-231 after 24,48 , and $72 \mathrm{~h}$, respectively [9]. The $\mathrm{IC}_{50}$ values of FAA were thus combined with the $\mathrm{IC}_{50}$ of TAM which resulted in more growth inhibition and less $\mathrm{IC}_{50}$ amount, as compared to the treatment with a single drug at 24,48 , and $72 \mathrm{~h}$. Combined treatment with the $\mathrm{IC}_{50}$ amount of FAA-TAM reduced the IC $_{50}$ value of MCF-7 significantly to $5.05 \mu \mathrm{g} / \mathrm{ml}, 3.8 \mu \mathrm{g} / \mathrm{ml}$ and $3.4 \mu \mathrm{g} / \mathrm{ml}$ after 24,48 , and $72 \mathrm{~h}$ respectively. The $\mathrm{IC}_{50}$ concentration of TAM against MDA-MB-231 significantly reduced in the presence of FAA to $5.27 \mu \mathrm{g} / \mathrm{ml}, 6.8 \mu \mathrm{g} / \mathrm{ml}$, and $0.73 \mu \mathrm{g} / \mathrm{ml}$ at 24,48 , and $72 \mathrm{~h}$, respectively (Figure 7 ).

Drug combination effects were analysed by the method of Chou and Talalay [13]. The varying concentrations of the combination, $\mathrm{IC}_{12.5}, \mathrm{IC}_{25}$, and $\mathrm{IC}_{50}$ concentration, demonstrated $\mathrm{CI}<1$, indicating synergistic effects, while $\mathrm{IC}_{75}$ showed moderate antagonism with a CI $>1$. The calculated
CI values for MDA-MB-231 cells treated with FAA-TAM showed a downtrend from $\mathrm{IC}_{12.5}$ to $\mathrm{IC}_{25}, \mathrm{IC}_{50}$, and $\mathrm{IC}_{75}$ at 24 and $48 \mathrm{~h}$. The result revealed that the interaction of FAATAM was synergism at $24 \mathrm{~h}$, even in low concentration, while only a high concentration $\left(\mathrm{IC}_{75}\right)$ of the combination at $48 \mathrm{~h}$ promoted synergism but for the doses below that showed antagonism $(\mathrm{CI}>1)$. Contrariwise, the CI values of FAATAM showed synergism was obtained only in the lowest concentration, while the higher concentration resulted in antagonism (Figure 8).

3.8. LC-MS Analysis of FAA Extract. Figure 9 shows LC-MS peaks for FAA and the chemical structure of major compounds while Table 1 shows the major compounds present in the extract with their molecular weight and molecular formula. Our findings indicated that the major compounds in FAA include pirimicarb, Asn Gly Met, Schizonepetoside E, tamsulosin, Lys Gln Ile, Istamycin C1, Netilmicin, Actinodaphnine, acetylcaranine, sphinganine, ripazepam, 
TABLE 1: LC-MS characterization of methanolic flower extract of Allium atroviolaceum.

\begin{tabular}{|c|c|c|c|c|}
\hline Peak number & Rt & Mass & Formula & Compound name \\
\hline 8 & 5.485 & 238.143 & $\mathrm{C}_{11} \mathrm{H}_{18} \mathrm{~N}_{4} \mathrm{O}_{2}$ & Pirimicarb \\
\hline 10 & 5.662 & 320.1157 & $\mathrm{C}_{11} \mathrm{H}_{20} \mathrm{~N}_{4} \mathrm{O}_{5} \mathrm{~S}$ & Asn Gly Met \\
\hline 11 & 5.848 & 348.1775 & $\mathrm{C}_{16} \mathrm{H}_{28} \mathrm{O}_{8}$ & Schizonepetoside E \\
\hline 15 & 5.9 & 408.1718 & $\mathrm{C}_{20} \mathrm{H}_{28} \mathrm{~N}_{2} \mathrm{O}_{5} \mathrm{~S}$ & Tamsulosin \\
\hline 17 & 5.915 & 387.2487 & $\mathrm{C}_{17} \mathrm{H}_{33} \mathrm{~N}_{5} \mathrm{O}_{5}$ & Lys Gln Ile \\
\hline 20 & 5.95 & 431.2753 & $\mathrm{C}_{19} \mathrm{H}_{37} \mathrm{~N}_{5} \mathrm{O}_{6}$ & Istamycin $\mathrm{Cl}$ \\
\hline 24 & 5.989 & 475.3017 & $\mathrm{C}_{21} \mathrm{H}_{41} \mathrm{~N}_{5} \mathrm{O}_{7}$ & Netilmicin \\
\hline 60 & 8.339 & 783.4845 & $\mathrm{C}_{45} \mathrm{H}_{70} \mathrm{NO}_{8} \mathrm{P}$ & $\operatorname{PE}(22: 6(4 Z, 7 Z, 10 Z, 13 Z, 16 Z, 19 Z) / 18: 4(6 Z, 9 Z, 12 Z, 15 Z))$ \\
\hline 61 & 9.846 & 311.1171 & $\mathrm{C}_{18} \mathrm{H}_{17} \mathrm{NO}_{4}$ & Actinodaphnine \\
\hline 63 & 12.087 & 313.131 & $\mathrm{C}_{18} \mathrm{H}_{19} \mathrm{NO}_{4}$ & Acetylcaranine \\
\hline 64 & 14.88 & 432.3255 & $\mathrm{C}_{27} \mathrm{H}_{44} \mathrm{O}_{4}$ & $\begin{array}{l}\text { (23S)-23,24,25- trihydroxyvitamin D3/(23S)- 23,24,25- } \\
\text { trihydroxycholecalciferol }\end{array}$ \\
\hline 65 & 14.417 & 287.2835 & $\mathrm{C}_{17} \mathrm{H}_{37} \mathrm{NO}_{2}$ & C17 sphinganine \\
\hline 68 & 18.315 & 412.2989 & $\mathrm{C}_{27} \mathrm{H}_{40} \mathrm{O}_{3}$ & $\begin{array}{l}\text { MID42047:(22E)-(24S)-1 } \alpha, 24- \\
\text { dihydroxy-26,27-cyclo-22,23- didehydro-20-epivitamin } \\
\text { D3/(22E)-(24S)-1 } \alpha, 2\end{array}$ \\
\hline 72 & 20.701 & 268.1322 & $\mathrm{C}_{15} \mathrm{H}_{16} \mathrm{~N}_{4} \mathrm{O}$ & Ripazepam \\
\hline 75 & 23.633 & 278.2254 & $\mathrm{C}_{18} \mathrm{H}_{30} \mathrm{O}_{2}$ & 9E,12Z,15Z-octadecatrienoic acid \\
\hline 77 & 23.946 & 240.1161 & $\mathrm{C}_{16} \mathrm{H}_{16} \mathrm{O}_{2}$ & Dimethylstilbestrol \\
\hline 82 & 25.069 & 426.2032 & $\mathrm{C}_{18} \mathrm{H}_{35} \mathrm{O}_{9} \mathrm{P}$ & Dolichyl phosphate D-mannose \\
\hline
\end{tabular}

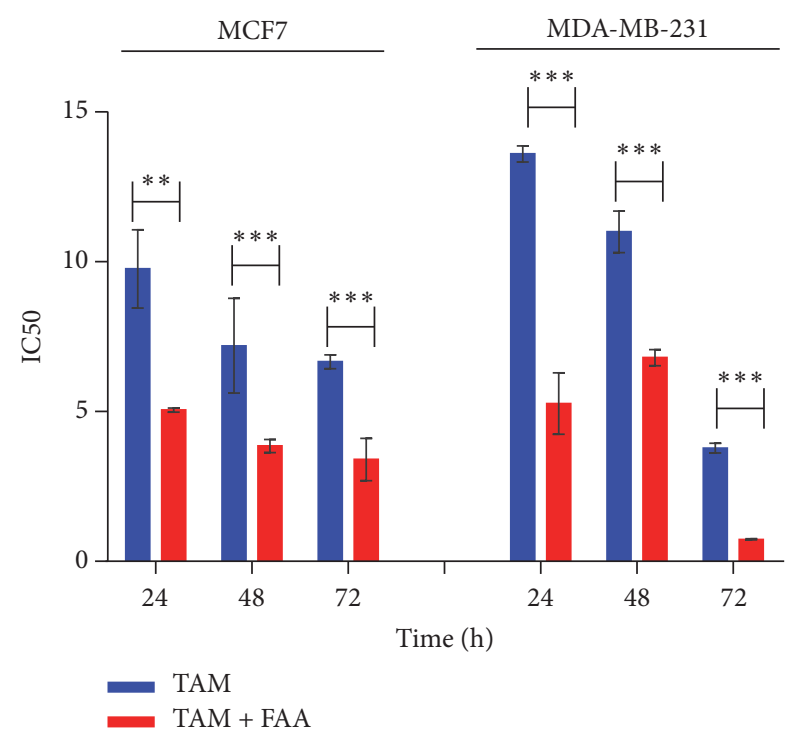

FIGURE 7: Interaction between TAM and FAA in MCF7 and MDA$M B-231$. Cells were treated with FA-TAM in a serial dilution for 24,48 , and $72 \mathrm{~h}$. Values are calculated from three independent experiments. ${ }^{*} p<0.05,{ }^{* *} p<0.01$, and ${ }^{* * *} p<0.001$ comparing the combination of TAM-FAA with TAM alone.

9E,12Z,15Z-octadecatrienoic acid, dimethylstilbestrol, and dolichyl phosphate D-mannose.

\section{Discussion}

This study represents the cytotoxic activity of FAA on human breast carcinoma cancer cell lines. Here, we have shown

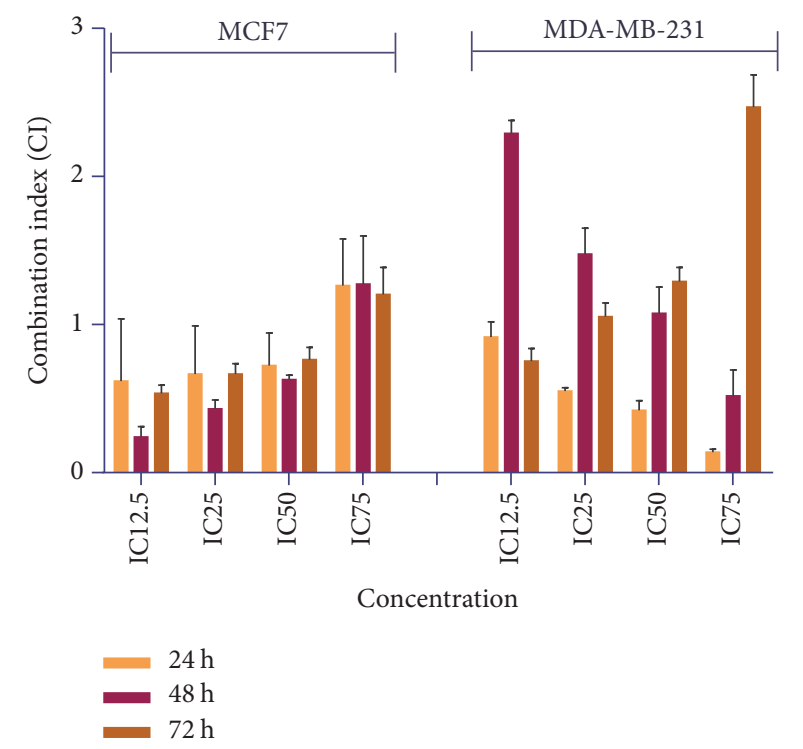

FIGURE 8: Combination index (CI) of cotreatment with TAM and FAA on MCF7 and MDA-MB-231. Cells were treated with FA-TAM in a serial dilution for 24,48 , and $72 \mathrm{~h}$. CI value was determined by Chou and Talalay method.

the molecular mechanisms of apoptosis induced by FAA in MCF-7 and MDA-MB-231 breast cancer cells. Current study revealed that FAA inhibits the proliferative activity of MCF7 and MDA-MB-231 cells. It is evident that cells exposed to FAA lose their capability to proliferate in a time- and dosedependent manner. This finding suggests that FAA has the 

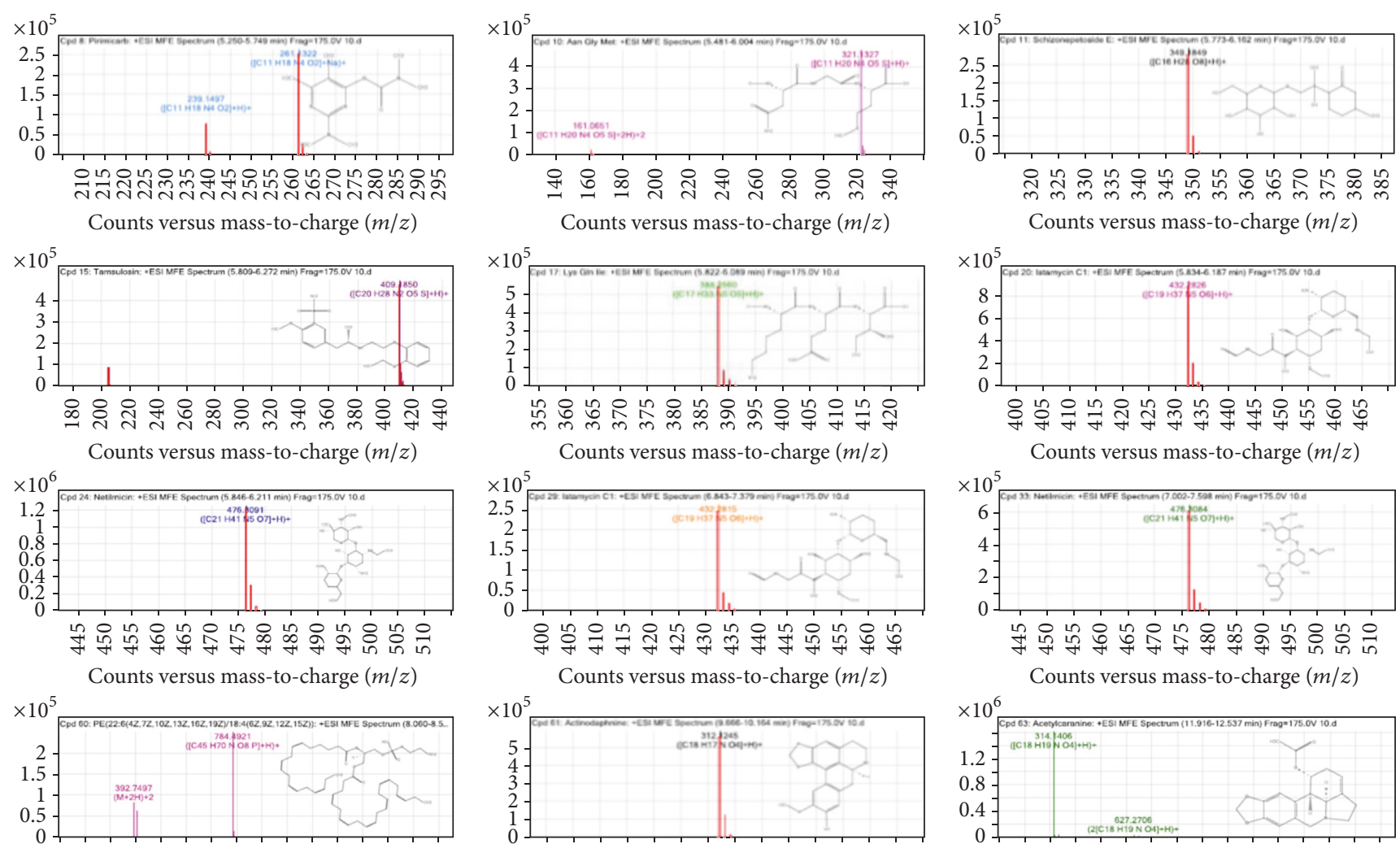

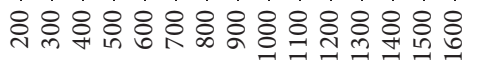

Counts versus mass-to-charge $(\mathrm{m} / \mathrm{z})$ $\times 10^{5}$

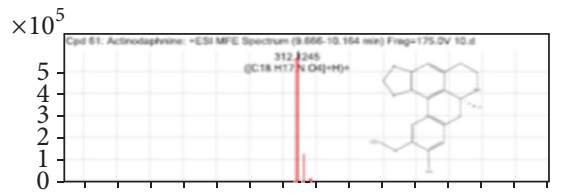

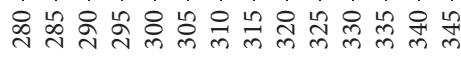

Counts versus mass-to-charge $(\mathrm{m} / \mathrm{z})$
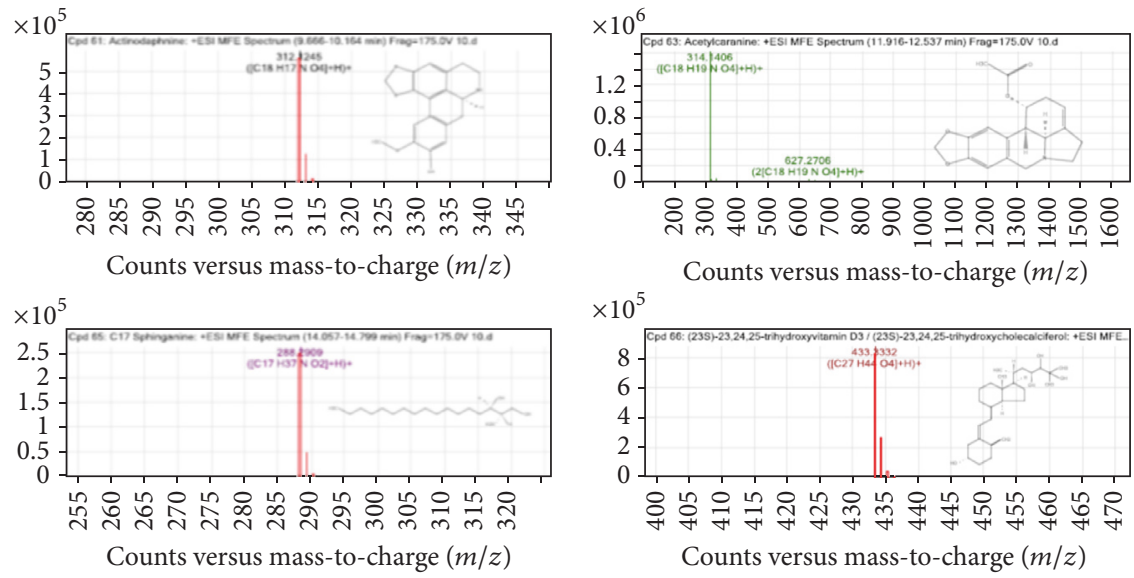

$\times 10^{5}$

Counts versus mass-to-charge $(\mathrm{m} / \mathrm{z})$
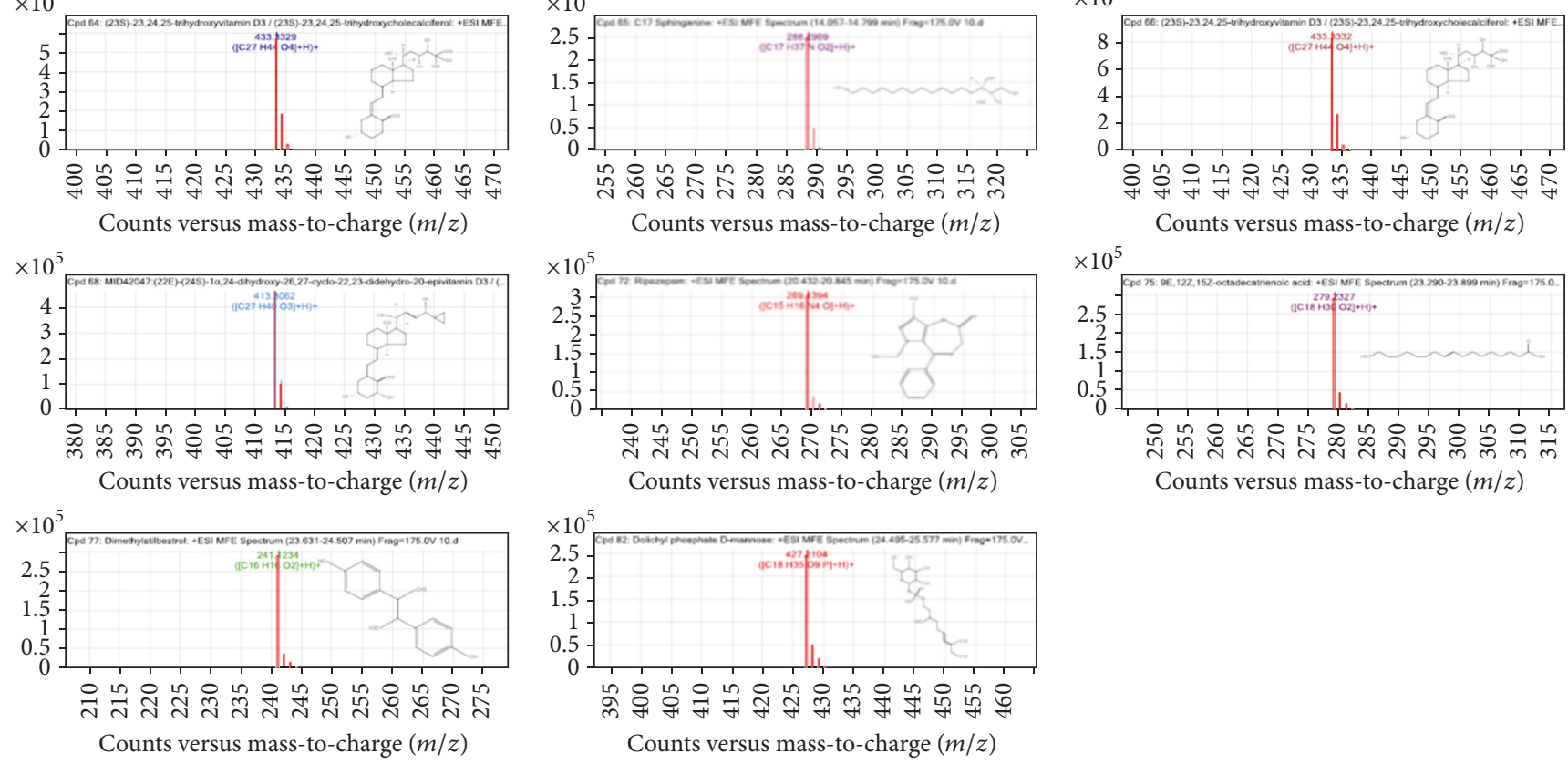

FIGURE 9: LC-MS tracings of the major compounds present in methanol extract of FAA.

potential to suppress the growth of the breast cancer cells irreversibly. In addition, a dramatic reduction in the number of viable cells suggests that the antiproliferative effect of FAA may be partly due to its ability to induce cell death. Moreover, it has been reported that the FAA extract does not show toxicity towards the normal cell [10].

The selective preference is fundamentally specific targeting of tumor cells which serves to enhance the therapeutic 
efficacy of cytotoxic drug, while at the same time reducing organ toxicities [14]. It is highly desirable to have substances which kill the cancer cells selectively, without damaging the adjacent normal cells [15].

Analyses of FAA-treated cells by phase contrast and fluorescence microscopy are the first evidence demonstrating that morphological changes characteristic of apoptotic cell death were induced by FAA. Apoptotic cells displayed distinctive typical forms of morphological changes that are widely used for the identification of apoptosis [16, 17]. Visualization of the control (untreated) cells by phase contrast microscope showed they maintained their original morphology form. In contrast, exposure of the cancer cells to FAA for 24, 48 , and $72 \mathrm{~h}$ exhibited classical morphologies of apoptosis, including autophagy and cell rounding due to shrinkage. After $24 \mathrm{~h}$ of treatment where the affected cells emerged, autophagy was achieved at maximum. In the remaining time interval, the occurrence of autophagy was not overlapped. It was caused mainly by the fact that the cell tried to gain a delay from cell death by autophagy [18], whereas, early stages of apoptosis, which are characterized by the shrinkage of cells and membrane blebbing, were clearly observed after $48 \mathrm{~h}$. The increasing time of exposure to FAA causes the cells to undergo late apoptosis/necrosis. The surface changes into a big, single bubble and eventually detached [15]. The apoptosis surface morphology observed was very similar for both cell types when treated with FAA. This implied that, regardless of the induction pathway, occurrence of apoptosis is concomitant with the same morphological alterations. This is consistent with the well-known highly conserved nature of apoptosis [19].

The morphological observation by AO/PI staining in the cell nuclei of MCF-7 and MDA-MB-231 breast cancer cells showed significant morphological alterations when compared to untreated control. Most AO+ and PI- apoptotic cells were noticed with chromatin condensation staining a brightgreen colour and nuclear margination, apoptotic granulation, and chromatin fragmentation with the appearances of membrane blebbing in some samples, which can be considered as moderate apoptosis. Increment of cell membrane permeability was observed after $72 \mathrm{~h}$ incubation, as evidenced by the apoptotic body separation and presence of reddish-orange colour due to the binding of AO to denatured DNA which can be seen clearly (AO+, PI+). Necrotic (AO-, PI+) cell populations appeared very rarely. Apoptosis and necrosis are the two major modes of cell death. Apoptosis is the more favorable mode of cell death because it is a programmed cell death mechanism that does not cause inflammatory responses. It is triggered and regulated by a variety of cellular signalling pathways. In contrast, necrotic cells are characterized by vacuolation of the cytoplasm and breakdown of plasma membrane. Due to this, the cytoplasmic elements are dispersed into the extracellular space, hence, resulting in an acute inflammatory reaction [20]. Analysis of the data disclosed that FAA had the ability to decrease the viability of MCF-7 and MDA-MB-231 cancer cells with no obvious necrotic phenomena, implying occurrence of a programmed cell death or induction of cell cycle arrest.
The cytotoxicity at the cellular level was assessed by measuring the DNA of the cancer cell in terms of distribution in cell cycle phase and ploidy level, as it flows through the cytometer [21]. Blockade of the cell cycle is considered as an effective strategy for the development of novel cancer therapies [22]. Cell cycle analysis of the treated MCF-7 revealed that FAA induced an S and G2/M phase cell cycle arrest at 24 and $48 \mathrm{~h}$ of treatment with an accompanying decrease in G1 phase and dose-dependent increase of subG0 phase. This confirmed that FAA inhibited DNA synthesis and induced a block at the S and G2/M phase boundary at 24 and $48 \mathrm{~h}$, while inducing apoptosis when exposed for longer time, whereas FAA arrested cell cycle progression in MDAMB-231 in S phase only after treatment for $72 \mathrm{~h}$, concomitant with a reduction of the cells presented in G1 phase and induction of apoptosis by increasing sub-G0 phase. The major control sites included DNA damage checkpoints (G0/G1, S, and $\mathrm{G} 2 / \mathrm{M})$. The drug interference with initiation of DNA replication can permanently arrest the cancer cells at the $S$ phase. Arrest in $S$ phase requires active suppression through transactivation of suppressors, direct binding of suppressors to replication machinery, and phosphorylation of critical elements of replication control [23]. We noted that FAA damage DNA and suppress DNA replication and eventually arrest the cells in $S$ phase. In addition, the $G_{2}$ checkpoint allows the cell to repair DNA damage before entering mitosis [24]. In MCF-7 cells, the result of cell cycle arrest suggests that, in addition to apoptosis and S phase arrest, G2 cell cycle arrest was another factor that contributed to the preferential cell growth inhibition.

Apoptosis confirmation was carried out using the simultaneous staining of cells with FITC-Annexin-V/PI, which allows the discrimination of intact cells (FITC- PI-), early apoptotic (FITC+ PI-), late apoptotic (FITC+ PI+), and necrotic cells (FITC-PI+) via bivariate analysis $[25,26]$. In the earlier events of apoptosis, membrane phospholipid phosphatidylserine (PS) is translocated from the inner to the outer leaflet of the cytoplasmic membrane and thereby exposed the PS to the external cellular environment. Translocation of PS to the outer leaflet is detectable by Annexin-V and can be quantitated using flow cytometry. Plasma membrane permeabilization converts the early apoptotic cells to late apoptotic cells. When the cytoplasmic membrane integrity is lost, the PI can penetrate to the nucleus and stain the DNA $[27,28]$. Treatment with FAA exhibited that FAA induced the exposure of phosphatidylserine on the surface of MCF7 in dose- and time-dependent manner. While in MDAMB-231 the treatment with low and middle concentrations $\left(\mathrm{IC}_{25}\right.$ and $\left.\mathrm{IC}_{50}\right)$ of FAA for 24 and $48 \mathrm{~h}$ resulted in more percentages of early apoptotic cells, the treatment for a longer time course $(72 \mathrm{~h})$ resulted in more cells present in the late apoptosis stage than early apoptosis. These results illustrated induction of apoptosis through multiple pathway, suggesting many compounds, rather than a single component in FAA.

Inflammation plays important roles in cancer and cancer cells produce many inflammatory mediators [29]. Although Caspases 1 and 5 play important roles in both inflammation and apoptosis [30], the role of caspases 1 and 5 in apoptosis was considered minor compared to the other caspases, in 
both MCF-7 and MDA-MB-231 cells. The caspase activity in treated MCF-7 revealed that FAA increased the activation of caspases 8 and 6 in all three used concentrations, while in only one concentration it increased caspase 9 (only in IC75) and caspase 3 (only in IC25) activities. The results illustrated that the apoptotic effects of FAA on MCF-7 cells were via the activation of caspase- 8 , which led to the activation of the final effector, caspase- 6 , that finally caused apoptosis. The only soluble cytosolic caspase which could cleave caspase- 8 is caspase- 6 [31]. In addition, caspase- 6 is required for the downstream activation of caspase-8 [32]. Caspase- 6 acts as an initiator caspase, by processing the initiator caspases 8 and 10, during apoptosis [33]. On the other hand, release of cytochrome $c$ from mitochondria activates the downstream caspases 2 and 9 that are early biomarkers of apoptosis and eventually lead to caspase- 3 activation, responsible for DNA fragmentation and morphological changes [34]. However, caspases 8 and 3 can cleave procaspase- 2 without prior dimerization [35]. On the other hand, caspase-1 and caspase5 are called inflammatory caspases, but they are also involved in the hydrolysis of procaspase- 3 to the activated caspase3 [29]. It is known that caspase-3 is a key mediator of nuclease activation that is triggered after the disruption of the mitochondrial membrane. Thus, caspase- 3 activation depends on release of cytochrome $c$ [36]. Therefore, this was aligned with our results, where, in the absence of caspase1 , caspase-5, caspase-2, and caspase- 9 activities, the executor caspase- 3 has been activated by $\mathrm{IC}_{25}$, probably from the other pathway.

In MDA-MB-231 cells, between the initiator caspases (caspases 2, 8, and 9), caspase-2 in $\mathrm{IC}_{50}$ and caspase-8 in $\mathrm{IC}_{50}$ and $\mathrm{IC}_{75}$, caspase- 9 in only the $\mathrm{IC}_{25}$ of FAA had significantly higher activity compared to the control. Among the executioner caspases (6 and 3), only caspase- 6 activity was raised in the $\mathrm{IC}_{50}$ of FAA. It can be concluded that, in different concentrations, various caspases are activated. In the $\mathrm{IC}_{50}$ concentration of FAA, initiator caspases 2 and 8 resulted in the activation of caspases 6 and 3, respectively. In $\mathrm{IC}_{25}$ and $\mathrm{IC}_{75}$ concentrations of FAA, none of the executioner caspases 3 or 6 was activated, while caspase- 9 and caspase8 were activated in at least one of these concentrations. Firstly, the results gave the possibility that apoptosis in MDA-MB-231 cells in these concentrations was not going through the caspase activation pathway. More and more studies have illustrated that apoptosis is not synonymous with the activation of caspases [37]. Secondly, maybe the executioner caspase-7 was activated in these concentrations. Both caspases 3 and 7 could be activated by caspases 8 and 9 during apoptosis. Caspases 3 and 7 have overlapping, but also distinct roles in apoptosis that is cell type and stimulus dependent [38].

$B c l-2$ family of genes plays a critical role in the regulation of the apoptotic process initiated at the mitochondria [39] and governed the mitochondrial outer membrane permeabilization [40]. Given that FAA has been identified as inducers of apoptosis, we sought to detect the $B c l-2$ mRNA level in MCF7 and MDA-MB-231 after treatment with FAA. The expression of $B c l-2$ exhibited an initial strong decrease, illustrating the potential of FAA to affect the transcriptional regulation of
$B c l-2$ and the degradation of its mRNA. Assessment of $B c l-2$ levels in both cells upon treatment by FAA also demonstrated some significant modulations, depending on the initial dose of exposure. The increment of FAA concentrations from $\mathrm{IC}_{25}$ to $\mathrm{IC}_{75}$ in MCF-7 cells showed a downward trend of $\mathrm{Bcl}$ 2 expression. On the other hand, MDA-MB-231 displayed a dramatic downregulation of $\mathrm{Bcl}-2$ in $\mathrm{IC}_{75}$ of FAA. The mechanism of apoptosis inhibition by $\mathrm{Bcl}-2$ is through the suppression of caspase proteins [41]. Caspase- 9 induces loss of mitochondrion membrane concomitant with the $\mathrm{Bcl}-2$ and $B c l-x L$ cleavage and therefore inactivates the antiapoptotic functions of these molecules and will potentially disrupt the balance between pro- and antiapoptotic molecules and induce cell death [42]. The $\mathrm{Bcl}-2$ expression observed in MCF-7 cells was aligned with the activity level of caspase-9, since downregulation of $\mathrm{Bcl}-2$ was concomitant with caspase9 activity. In contrast, the result of MDA-MB-231, which was in an argument with the observation of caspase- 9 activity, demonstrated that FAA lead to $\mathrm{Bcl}-2$ downregulation, without impairing the mitochondrial functions which confirm the extramitochondrial roles of $B c l-2$.

Cell cycle regulatory proteins had been considered as predictive markers in cancers. Cyclin-dependent protein kinases $(C d k s)$ are key signalling molecules in the regulation of cell cycle [43] for entry into mitosis and a core component in spindle morphogenesis [44]. Cdk1 is the only necessary $C d k$ in the process of cell proliferation through mitosis. As Cdk1 inhibitors effectively arrested tumor cell growth, finding the new Cdk1 inhibitors is a new target in the research and development of anticancer drugs $[45,46]$. It has been evident that $C d k 1$, which is overexpressed and have enhanced kinase activity in many tumor types, is the potential targets for cancer therapy [47]. FAA extract succeeded in reducing the expression of $C d k 1$ in both cells in a dosedependent manner, as $\mathrm{IC}_{75}$ showed the significantly lower expression in MCF-7 and MDA-MB-231. The inhibition of G2/M progression induced by FAA in MCF-7 suggests that the Cdk1-cyclin B complex regulates the G2 to $\mathrm{M}$ transition and resulted in the antiproliferative effect of FAA. In contrast, although downregulation of $C d k 1$ occurred in MDA-MB231, only sub-G0/G1 phase arrest was observed (in the same concentration at $24 \mathrm{~h}$ ) that demonstrated apoptosis in this cell line. Since $C d k 1$ transcription is controlled by various factors, we hypothesize that treatment with FAA in MDA-MB231 may affect $C d k 1$ transcription via inhibition of protein kinases involved in the upstream regulation of this gene [48]. Moreover, it has been shown that $C d k 1$ may be required for apoptosis, independent of the cell cycle regulation [49].

The $p 53$ tumor suppressor gene includes various functional categories and plays a role in repair of DNA damage, cell cycle progression, and apoptosis [50]. The activation of specific p 53 response could be determined by the specific transcriptional targets and roles in subcellular pathways [51]. In the current study, p53 expression in MCF-7 and MDAMB-231 was not significantly upregulated. The current study did not exclude the possibility that some of the cells that were negative for nuclear $p 53$ expression may have a $p 53$ gene mutation [52]. About $50 \%$ of all cancer cases possess a p53 mutation with loss of its tumor suppressor activities; 
therefore these cases are resistant to apoptosis and required new drugs that act in a p53-independent pathways [53]. The novel plant extract FAA demonstrated the ability to kill breast cancer cells by a p53-independent mechanism, while it was associated with extrinsic or intrinsic signalling pathway and downregulation of $\mathrm{Bcl}-2$, depending on the concentrations.

Since cancer is the result of numerous mutations reposition, combination of two or more drugs with different mechanisms of action may lead to enhancing cell death [54]. FAA could be useful in synergizing the efficacy of TAM in both MCF-7 and MDA-MB231 cells. The significance of this finding lies in the fact that, besides its therapeutic potency, TAM cause high toxicity to the normal tissues and harmful effects on health and development of primary and secondary drug resistance limiting its clinical success in the cancer chemotherapy. In this regard, current report shows that combination of chemotherapeutic agents with naturally occurring dietary supplements is a preferable modality for cancer treatment than single-agent that might also reduce systemic toxicity of the chemotherapeutic agents [55].

LC-MS was utilized to separate and evaluate chemical constituents in FAA which indicated the presence of different phytochemicals in the respective extract with various biological actions such as antioxidant and anticancer activates. For instance, sulfonamide derivatives tamsulosin reduces prostate smooth muscle tone and thereby inhibits the dynamic component of the obstruction, utilized in prostate cancer [56]. Actinodaphnine, an aporphine alkaloid, has been shown to possess antitopoisomerases, antibacterial, antifungal, and anticancer properties. It also possesses antiplatelet aggregation and vasorelaxant activity [57]. Acetylcarnitine is an acetylated form of carnitine which has antioxidant activities through direct scavenging free radicals and chelating catalytic metals-promoters of reactive oxidative species (ROS) [58]. Trihydroxyvitamin D3 is a product of vitamin D3 metabolism; several vitamin D analogs are entering clinical trials and are showing great promise as potential therapeutic agents for the treatment of cancer and other diseases [59]. Sphingoid bases may function as chemotherapeutic as well as chemopreventive agents by preferentially inhibiting cancer cells and eliminating stem cells from which most breast cancer cells arise [60]. 9,12,15-Octadecatrienoic acid is another major compound in the studied plant extracts and has been reported to have antimicrobial, antioxidant, and anti-inflammatory activities [61]. The results show that the occurrence of the variable compounds may be responsible for the different extent of anticancer activity shown by the test extract.

\section{Conclusion}

In conclusion, FAA inhibited cell proliferation MCF-7 and MDA-MB-231 cells through stimulation of cell-specific $S$ and G2/M arrest in MCF-7 and S cell cycle phase arrest in MDAMB-231 accompanied by induction of apoptosis through both extrinsic and intrinsic apoptotic pathways, probably in the result of biological properties of phytochemicals present in FAA extract. In addition, the FAA-induced apoptosis in both cells is likely to be caspase-dependent, $B c l$-2-dependent, and p53-transcription-independent. FAA also exhibited synergistic effect when combined with TAM, suggesting that it can complement current chemotherapeutic treatment.

\section{Conflicts of Interest}

The authors declare no conflicts of interest.

\section{Acknowledgments}

The authors acknowledge the Malaysian Genome Institute for the technical assistance in the use of the Bioanalyser. Special thanks are due to Dr. Dehpour from Azad University of Ghaemshahr, Iran, for identification of the plant species and voucher number.

\section{References}

[1] E. Azizi, M. H. Abdolmohammadi, S. Fouladdel, A. Shafiee, G. Amin, and S. M. Ghaffari, "Evaluation of p53 and BCL-2 genes and proteins expression in human breast cancer T47D cells treated with extracts of Astrodaucus persicus (Boiss.) drude in comparison to tamoxifen," DARU Journal of Pharmaceutical Sciences, vol. 17, no. 3, pp. 181-186, 2009.

[2] B. Pratumvinit, T. Srisapoomi, P. Worawattananon, N. Opartkiattikul, W. Jiratchariyakul, and T. Kummalue, "In vitro antineoplastic effect of Ficus hispida L. plant against breast cancer cell lines," Journal of Medicinal Plants Research, vol. 3, no. 4, pp. 255261, 2009.

[3] A. I. Elkady, O. A. Abuzinadah, N. A. Baeshen, and T. R. Rahmy, "Differential control of growth, apoptotic activity, and gene expression in human breast cancer cells by extracts derived from medicinal herbs Zingiber officinale," Journal of Biomedicine and Biotechnology, vol. 2012, Article ID 614356, 14 pages, 2012.

[4] A. Saetung, A. Itharat, C. Dechsukum, C. Wattanapiromsakul, N. Keawpradub, and P. Ratanasuwan, "Cytotoxic activity of Thai medicinal plants for cancer treatment," Songklanakarin J Sci Technol, vol. 27, no. 2, pp. 469-478.

[5] A. Afonin, S. Greene, N. Dzyubenko, and A. Frolov, Interactive agricultural ecological atlas of Russia and neighboring countries. Economic plants and their diseases, pests and weeds, 2008.

[6] D. Mitroi, D. Anton, C. Nicu, and M. Manda, "Variability of decorative morphological characteristics in the species papaver rhoeas of spontaneous vegetation," South-Western Journal of Horticulture Biology and Environment, vol. 1, no. 1, pp. 21-27.

[7] A. A. Dehpour, B. Babakhani, S. Khazaei, and M. Asadi, "Chemical composition of essential oil and antibacterial activity of extracts from flower of Allium atroviolaceum," Journal of Medicinal Plants Research, vol. 5, no. 16, pp. 3667-3672, 2011.

[8] A. Sengupta, S. Ghosh, and S. Bhattacharjee, "Allium vegetables in cancer prevention: An overview," Asian Pacific Journal of Cancer Prevention, vol. 5, no. 3, pp. 237-245, 2004.

[9] S. Khazaei, N. M. Esa, V. Ramachandran et al., "In vitro antiproliferative and apoptosis inducing effect of Allium atroviolaceum bulb extract on breast, cervical, and liver cancer cells," Frontiers in Pharmacology, vol. 8, article no. 5, 2017.

[10] S. Khazaei, R. Abdul Hamid, N. Mohd Esa et al., "Promotion of HepG2 cell apoptosis by flower of Allium atroviolaceum and the mechanism of action," BMC Complementary and Alternative Medicine, vol. 17, no. 1, article no. 104, 2017. 
[11] S. Khazaei, V. Ramachandran, R. Abdul hamid et al., "Flower extract of Allium atroviolaceum triggered apoptosis, activated caspase- 3 and down-regulated antiapoptotic Bcl-2 gene in HeLa cancer cell line," Biomedicine \& Pharmacotherapy, vol. 89, pp. 1216-1226, 2017.

[12] C.-C. Chang, Y.-C. Liang, A. Klutz et al., "Reversal of multidrug resistance by two nordihydroguaiaretic acid derivatives, M4N and maltose-M3N, and their use in combination with doxorubicin or paclitaxel," Cancer Chemotherapy and Pharmacology, vol. 58, no. 5, pp. 640-653, 2006.

[13] J. Zhao, K. Kelnar, and A. G. Bader, "In-depth analysis shows synergy between erlotinib and miR-34a," PLoS ONE, vol. 9, no. 2, Article ID e89105, 2014.

[14] H. M. M. Arafa, "Possible contribution of $\beta$-glucosidase and caspases in the cytotoxicity of glufosfamide in colon cancer cells," European Journal of Pharmacology, vol. 616, no. 1-3, pp. 58-63, 2009.

[15] S. N. Syed Abdul Rahman, N. Abdul Wahab, and S. N. Abd Malek, "In vitro morphological assessment of apoptosis induced by antiproliferative constituents from the rhizomes of curcuma zedoaria," Evidence-Based Complementary and Alternative Medicine, vol. 2013, Article ID 257108, 14 pages, 2013.

[16] H. J. Brady, Apoptosis Methods and Protocols, vol. 282, Humana Press, New York, NY, USA, 2004.

[17] P. Moongkarndi, N. Kosem, S. Kaslungka, O. Luanratana, N. Pongpan, and N. Neungton, "Antiproliferation, antioxidation and induction of apoptosis by Garcinia mangostana (mangosteen) on SKBR3 human breast cancer cell line," Journal of Ethnopharmacology, vol. 90, no. 1, pp. 161-166, 2004.

[18] L. Mazalova, J. Balvan, H. Polanska, and Z. Sladek, Occurrence of cell death in cancer cell line PC-3 after treatment of plumbagin,.

[19] S. Rello, J. C. Stockert, V. Moreno et al., "Morphological criteria to distinguish cell death induced by apoptotic and necrotic treatments," Apoptosis, vol. 10, no. 1, pp. 201-208, 2005.

[20] A. L. Edinger and C. B. Thompson, "Death by design: apoptosis, necrosis and autophagy," Current Opinion in Cell Biology, vol. 16, no. 6, pp. 663-669, 2004.

[21] R. Mathur, S. K. Gupta, N. Singh, S. Mathur, V. Kochupillai, and T. Velpandian, "Evaluation of the effect of Withania somnifera root extracts on cell cycle and angiogenesis," Journal of Ethnopharmacology, vol. 105, no. 3, pp. 336-341, 2006.

[22] S. Gu and J. He, "Daphnoretin induces cell cycle arrest and apoptosis in human osteosarcoma (HOS) cells," Molecules, vol. 17, no. 1, pp. 598-612, 2012.

[23] F. Borel, F. B. Lacroix, and R. L. Margolis, "Prolonged arrest of mammalian cells at the G1/S boundary results in permanent $S$ phase stasis," Journal of Cell Science, vol. 115, no. 14, pp. 28292838, 2002.

[24] R. S. DiPaola et al., "To arrest or not to $\mathrm{G}_{2}-\mathrm{M}$ cell-cycle arrest commentary re: AK Tyagi et al., silibinin strongly synergizes human prostate carcinoma DU145 cells to doxorubicin-induced growth inhibition, G2-M arrest, and apoptosis. Clin. Cancer Res., 8: 3512-3519, 2002," Clinical cancer research, vol. 8, no. 11, pp. 3512-3519, 2002.

[25] M. H. Abdolmohammadi, S. Fouladdel, A. Shafiee, G. Amin, S. M. Ghaffari, and E. Azizi, "Antiproliferative and apoptotic effect of Astrodaucus orientalis (L.) drude on T47D human breast cancer cell line: Potential mechanisms of action," African Journal of Biotechnology, vol. 8, no. 17, pp. 4265-4276, 2009.

[26] W.-S. Juan, H.-W. Lin, Y.-H. Chen et al., "Optimal Percoll concentration facilitates flow cytometric analysis for annexin
V/propidium iodine-stained ischemic brain tissues," Cytometry Part A, vol. 81, no. 5, pp. 400-408, 2012.

[27] T. S. Hawley and R. G. Hawley, Flow Cytometry Protocols, vol. 91, Humana Press, New York, NY, USA, 2 edition, 2004.

[28] I. K. H. Poon, M. D. Hulett, and C. R. Parish, "Molecular mechanisms of late apoptotic/necrotic cell clearance," Cell Death \& Differentiation, vol. 17, no. 3, pp. 381-397, 2010.

[29] E. Babas, M. T. Ekonomopoulou, I. Karapidaki, A. Doxakis, G. Betsas, and Z. Iakovidou-Kritsi, "Indication of participation of caspase- 2 and caspase- 5 in mechanisms of human cervical malignancy," International Journal of Gynecological Cancer : official journal of the International Gynecological Cancer Society, vol. 20, no. 8, pp. 1381-1385, 2010.

[30] Y. H. Soung, E. G. Jeong, C. H. Ahn et al., "Mutational analysis of caspase 1, 4, and 5 genes in common human cancers," Human Pathology, vol. 39, no. 6, pp. 895-900, 2008.

[31] V. Cowling and J. Downward, "Caspase-6 is the direct activator of caspase- 8 in the cytochrome c-induced apoptosis pathway: Absolute requirement for removal of caspase- 6 prodomain," Cell Death \& Differentiation, vol. 9, no. 10, pp. 1046-1056, 2002.

[32] M. Kruidering and G. I. Evan, "Caspase- 8 in apoptosis: the beginning of 'the end'?" IUBMB Life, vol. 50, no. 2, pp. 85-90, 2000.

[33] J. H. Cho, P. Y. Lee, W.-C. Son et al., "Identification of the novel substrates for caspase- 6 in apoptosis using proteomic approaches," BMB Reports, vol. 46, no. 12, pp. 588-593, 2013.

[34] M. F. Abu Bakar, M. Mohamad, A. Rahmat, S. A. Burr, and J. R. Fry, "Cytotoxicity, cell cycle arrest, and apoptosis in breast cancer cell lines exposed to an extract of the seed kernel of Mangifera pajang (bambangan)," Food and Chemical Toxicology, vol. 48, no. 6, pp. 1688-1697, 2010.

[35] M. E. Delgado, M. Olsson, F. A. Lincoln, B. Zhivotovsky, and M. Rehm, "Determining the contributions of caspase-2, caspase- 8 and effector caspases to intracellular VDVADase activities during apoptosis initiation and execution," Biochimica et Biophysica Acta (BBA) - Molecular Cell Research, vol. 1833, no. 10, pp. 22792292, 2013.

[36] Y. Liang, C. Yan, and N. F. Schor, "Apoptosis in the absence of caspase 3," Oncogene, vol. 20, no. 45, pp. 6570-6578, 2001.

[37] L. C.-M. Chiu, T.-S. Ho, E. Y.-L. Wong, and V. E. C. Ooi, "Ethyl acetate extract of Patrinia scabiosaefolia downregulates antiapoptotic $\mathrm{Bcl}-2 / \mathrm{Bcl}-\mathrm{X}_{L}$ expression, and induces apoptosis in human breast carcinoma MCF-7 cells independent of caspase- 9 activation," Journal of Ethnopharmacology, vol. 105, no. 1-2, pp. 263-268, 2006.

[38] M. Lamkanfi and T.-D. Kanneganti, "Caspase-7: a protease involved in apoptosis and inflammation," The International Journal of Biochemistry \& Cell Biology, vol. 42, no. 1, pp. 21-24, 2010.

[39] E. I. Papadopoulos, G. M. Yousef, and A. Scorilas, "Cytotoxic activity of sunitinib and everolimus in Caki-1 renal cancer cells is accompanied by modulations in the expression of apoptosisrelated microRNA clusters and BCL2 family genes," Biomedicine \& Pharmacotherapy, vol. 70, no. C, pp. 33-40, 2015.

[40] Ö. Çakir, M. Pekmez, E. Çepni, B. Candar, and K. Fidan, "Evaluation of biological activities of physalis peruviana ethanol extracts and expression of Bcl-2 genes in HeLa cells," Food Science and Technology, vol. 34, no. 2, pp. 422-430, 2014.

[41] L. Shi, H. Teng, M. Zhu et al., "Paeoniflorin inhibits nucleus pulposus cell apoptosis by regulating the expression of Bcl-2 family proteins and caspase-9 in a rabbit model of intervertebral disc degeneration," Experimental and Therapeutic Medicine, vol. 10, no. 1, pp. 257-262, 2015. 
[42] M. Chen, A. D. Guerrero, L. Huang et al., "Caspase-9-induced mitochondrial disruption through cleavage of anti-apoptotic BCL-2 family members," The Journal of Biological Chemistry, vol. 282, no. 46, pp. 33888-33895, 2007.

[43] R. M. Golsteyn, "Cdk1 and Cdk2 complexes (cyclin dependent kinases) in apoptosis: A role beyond the cell cycle," Cancer Letters, vol. 217, no. 2, pp. 129-138, 2005.

[44] S. Chen, X. Chen, Y.-L. Xiu, K.-X. Sun, and Y. Zhao, "MicroRNA490-3P targets CDK1 and inhibits ovarian epithelial carcinoma tumorigenesis and progression," Cancer Letters, vol. 362, no. 1, pp. 122-130, 2015.

[45] M. A. Al-Sha'Er and M. O. Taha, "Discovery of novel CDK1 inhibitors by combining pharmacophore modeling, QSAR analysis and in silico screening followed by in vitro bioassay," European Journal of Medicinal Chemistry, vol. 45, no. 9, pp. 4316-4330, 2010.

[46] H.-M. Guo, Y.-M. Sun, S.-X. Zhang et al., "Metabolism and pharmacokinetics of 8-hydroxypiperidinylmethyl-baicalein (BA-j) as a novel selective CDK1 inhibitor in monkey," Fitoterapia, vol. 107, pp. 36-43, 2015.

[47] Y. Matthess, M. Raab, R. Knecht, S. Becker, and K. Strebhardt, "Sequential Cdk1 and Plk1 phosphorylation of caspase- 8 triggers apoptotic cell death during mitosis," Molecular Oncology, vol. 8, no. 3, pp. 596-608, 2014.

[48] W.-I. Jang, Z.-L. Lin, S. H. Lee, S. Namgoong, and N.-H. Kim, "A specific inhibitor of CDK1, RO-3306, reversibly arrests meiosis during in vitro maturation of porcine oocytes," Animal Reproduction Science, vol. 144, no. 3-4, pp. 102-108, 2014.

[49] F. Hongo, N. Takaha, M. Oishi et al., "CDK1 and CDK2 activity is a strong predictor of renal cell carcinoma recurrence," Urologic Oncology: Seminars and Original Investigations, vol. 32, no. 8, pp. 1240-1246, 2014.

[50] C. Balachandran, B. Sangeetha, V. Duraipandiyan et al., "A flavonoid isolated from Streptomyces sp. (ERINLG-4) induces apoptosis in human lung cancer A549 cells through p53 and cytochrome c release caspase dependant pathway," ChemicoBiological Interactions, vol. 224, pp. 24-35, 2014.

[51] A. A. Alshatwi, P. Subash-Babu, and P. Antonisamy, "Violacein induces apoptosis in human breast cancer cells through up regulation of BAX, p53 and down regulation of MDM2," Experimental and Toxicologic Pathology, vol. 68, no. 1, pp. 8997, 2016.

[52] M. Jiang and J. Milner, "Bcl-2 constitutively suppresses p53dependent apoptosis in colorectal cancer cells," Genes \& Development, vol. 17, no. 7, pp. 832-837, 2003.

[53] C. F. Lima, M. Costa, M. F. Proença, and C. Pereira-Wilson, "Novel structurally similar chromene derivatives with opposing effects on p53 and apoptosis mechanisms in colorectal HCT116 cancer cells," European Journal of Pharmaceutical Sciences, vol. 72, article no. 3202, pp. 34-45, 2015.

[54] F. C. Wong, C. C. Woo, A. Hsu, and B. K. H. Tan, "The AntiCancer Activities of Vernonia amygdalina Extract in Human Breast Cancer Cell Lines Are Mediated through CaspaseDependent and p53-Independent Pathways," PLoS ONE, vol. 8, no. 10, Article ID e78021, 2013.

[55] G. Sharma, A. K. Tyagi, R. P. Singh, D. C. F. Chan, and R. Agarwal, "Synergistic anti-cancer effects of grape seed extract and conventional cytotoxic agent doxorubicin against human breast carcinoma cells," Breast Cancer Research and Treatment, vol. 85, no. 1, pp. 1-12, 2004.
[56] A. Tahmatzopoulos, R. G. Rowland, and N. Kyprianou, "The role of $\alpha$-blockers in the management of prostate cancer," Expert Opinion on Pharmacotherapy, vol. 5, no. 6, pp. 1279-1285, 2004.

[57] T.-J. Hsieh, T.-Z. Liu, F.-J. Lu, P.-Y. Hsieh, and C.-H. Chen, "Actinodaphnine induces apoptosis through increased nitric oxide, reactive oxygen species and down-regulation of NF$\kappa \mathrm{B}$ signaling in human hepatoma Mahlavu cells," Food and Chemical Toxicology, vol. 44, no. 3, pp. 344-354, 2006.

[58] P. F. Surai, "Antioxidant action of carnitine: molecular mechanisms and practical applications," EC Veterinary Science, vol. 2, pp. 66-84, 2015.

[59] W. Li, J. Chen, Z. Janjetovic et al., "Chemical synthesis of 20Shydroxyvitamin D3, which shows antiproliferative activity," Steroids, vol. 75, no. 12, pp. 926-935, 2010.

[60] H. A. Eun, C.-C. Chang, and J. J. Schroeder, "Evaluation of sphinganine and sphingosine as human breast cancer chemotherapeutic and chemopreventive agents," Experimental Biology and Medicine, vol. 231, no. 10, pp. 1664-1672, 2006.

[61] S. Mickymaray, M. S. Al Aboody, P. K. Rath, P. Annamalai, and T. Nooruddin, "Screening and antibacterial efficacy of selected Indian medicinal plants," Asian Pacific Journal of Tropical Biomedicine, vol. 6, no. 3, pp. 185-191, 2016. 


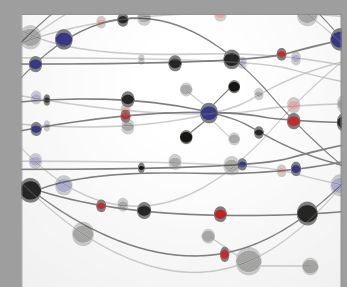

The Scientific World Journal
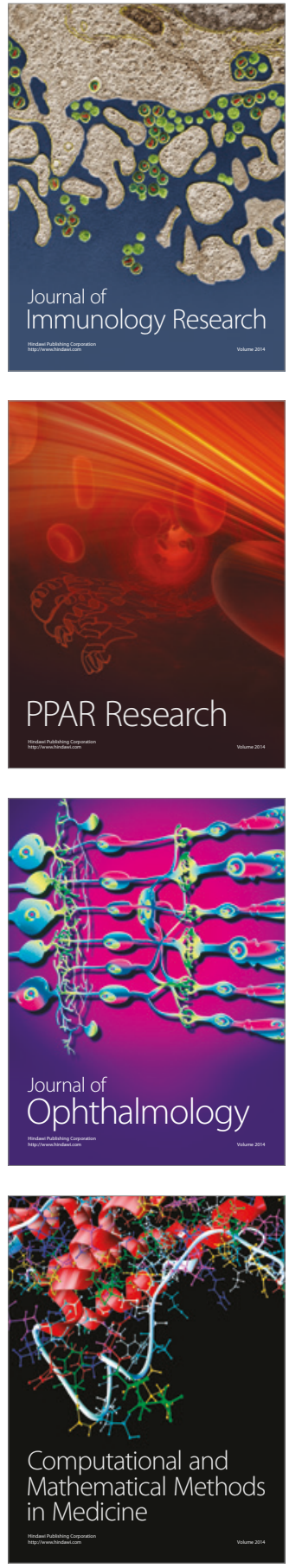

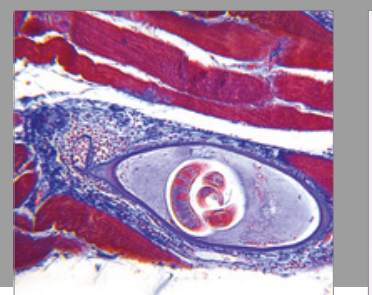

Gastroenterology Research and Practice
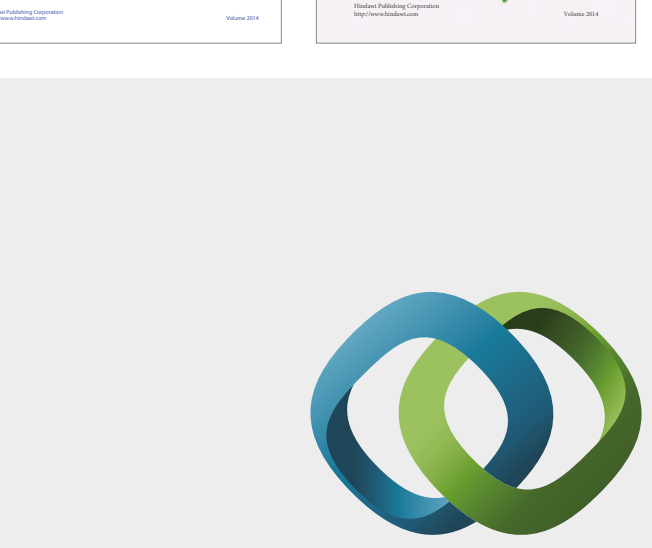

\section{Hindawi}

Submit your manuscripts at

https://www.hindawi.com
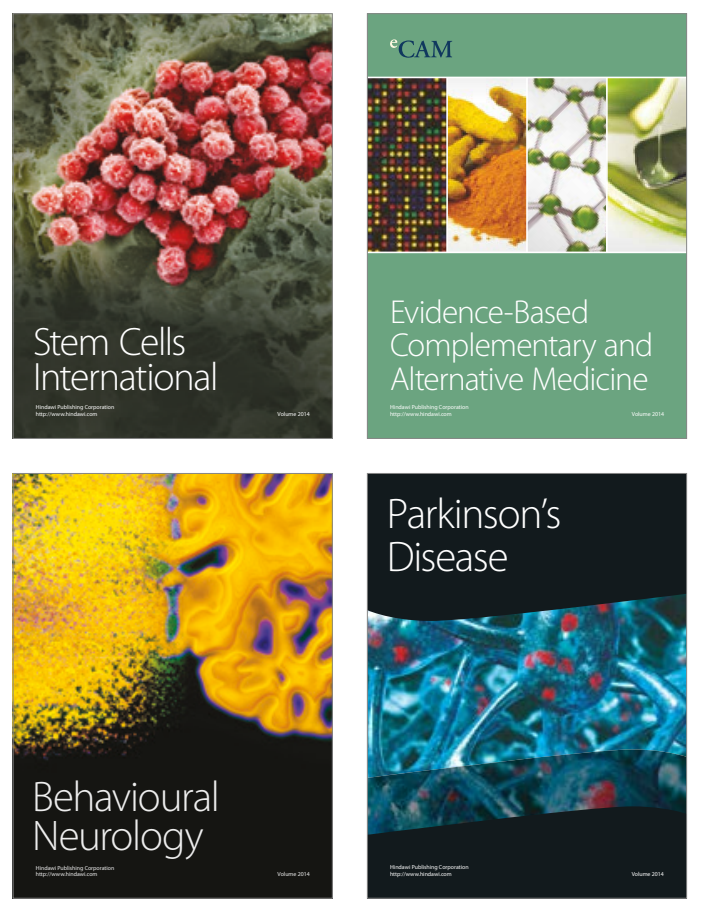
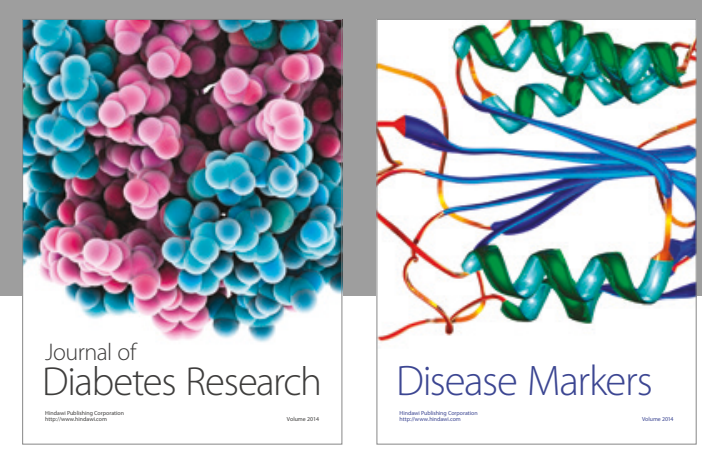

Disease Markers
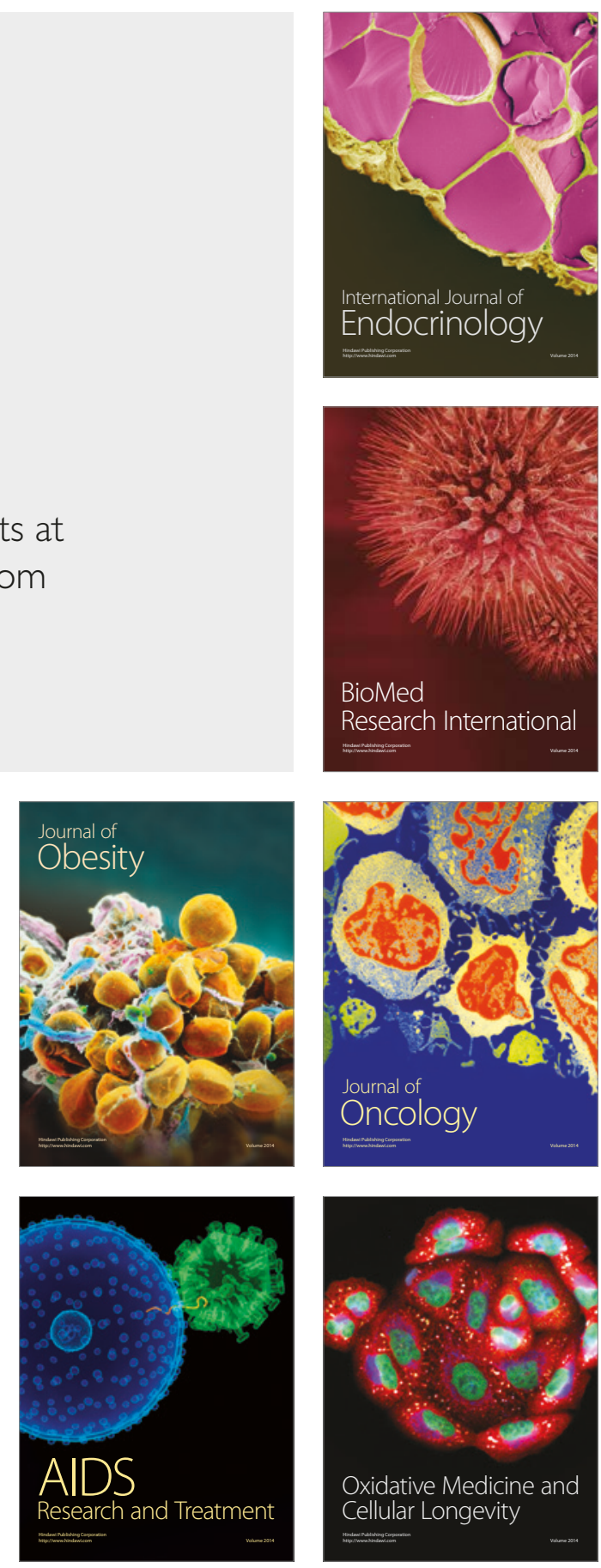